\title{
Deep structure of Pyrenees range (SW Europe) imaged by joint inversion of gravity and teleseismic delay time
}

\author{
Grégory Dufréchou, ${ }^{1}$ Christel Tiberi, ${ }^{2}$ Roland Martin, ${ }^{1}$ Sylvain Bonvalot, ${ }^{1}$ \\ Sébastien Chevrot $^{1}$ and Lucia Seoane ${ }^{1}$ \\ ${ }^{1}$ Géosciences Environnement Toulouse, Observatoire Midi-Pyrénées, CNES, CNRS, IRD, UPS, 31400 Toulouse, France. E-mail: \\ gregory.dufrechou@gmail.com \\ ${ }^{2}$ Géosciences Montpellier, CNRS, Univ. Montpellier, 34090 Montpellier, France
}

Received 2018 March 19; in original form 2017 December 22

\begin{abstract}
SUMMAR Y
We present a new model of the lithosphere and asthenosphere structure down to $300 \mathrm{~km}$ depth beneath the Pyrenees from the joint inversion of recent gravity and teleseismic data. Unlike previous studies, crustal correction was not applied on teleseismic data in order (i) to preserve the consistency between gravity data, which are mainly sensitive to the density structure of the crust lithosphere, and traveltime data, and (ii) to avoid the introduction of biases resulting from crustal reductions. The density model down to $100 \mathrm{~km}$ depth is preferentially used here to discuss the lithospheric structure of the Pyrenees, whereas the asthenospheric structure from 100 to $300 \mathrm{~km}$ depth is discussed from our velocity model. The absence of a high density anomaly in our model between 30 and $100 \mathrm{~km}$ depth (except the Labourd density anomaly) in the northern part of the Pyrenees seems to preclude eclogitization of the subducted Iberian crust at the scale of the entire Pyrenean range. Local eclogitization of the deep Pyrenean crust beneath the western part of the Axial Zone (west of Andorra) associated with the positive central density anomaly is proposed. The Pyrenean lithosphere in density and velocity models appears segmented from east to west. No clear relation between the along-strike segmentation and mapped major faults is visible in our models. The Pyrenees' lithosphere segments are associated with different seismicity pattern in the Pyrenees suggesting a possible relation between the deep structure of the Pyrenees and its seismicity in the upper crust. The concentration of earthquakes localized just straight up the central density anomaly can reflect the subsidence and/or delamination of an eclogitized Pyrenean deep root. The velocity model in the asthenosphere is similar to previous studies. The absence of a high-velocity anomaly in the upper mantle and transition zone (i.e. 125 to $225 \mathrm{~km}$ depth) seems to preclude the presence of a detached oceanic lithosphere beneath the European lithosphere.
\end{abstract}

Key words: Joint inversion; Seismic tomography; Gravity anomalies and Earth structure; Continental margins: convergent; Europe; Seismicity and tectonics.

\section{INTRODUCTION}

The Pyrenees correspond to a roughly EW-trending $c a .450 \mathrm{~km}$ long and $c a .125 \mathrm{~km}$ wide continental fold-and-thrust belt in SW Europe resulting from the convergence of Eurasia and Iberia plates (Vissers \& Meijer 2012a,b, and references therein; Fig. 1a). The Pyrenees' components were affected by a complex geodynamic evolution through two major periods: (i) the Variscan cycle that encompasses the Paleotethys subduction and later collision between Laurussia and Gondwana (Matte 1986; Burg et al. 1994), and (ii) the Alpine cycle through the opening of the Bay of Biscay and the formation of the Pyrenees from the convergence of Iberia and Eurasia plates (Le Pichon et al. 1970; Sibuet et al. 2004; Vissers \& Meijer 2012a,b). Numerous geophysical and geological experiments have been conducted in the Pyrenees, where strong controversies are still prevailing concerning the global rate of shortening of the mountain range and the relative displacement of Iberia and Eurasia plates during the Cretaceous (e.g. Vissers \& Meijer 2012a,b; Vanderhaeghe \& Grabkowiak 2014; Barnett-Moore et al. 2016). Two kinematic scenarios generally imply: (i) a mainly sinistral strike-slip displacement occurring along the North Pyrenean Fault (e.g. Le Pichon et al. 1970; Mattauer \& Séguret 1971; Choukroune \& Mattauer 1978), or (ii) a scissor-type opening implying the simultaneous subduction of a $c a .300 \mathrm{~km}$ wide ocean or exhumed mantle domain between Iberia and Eurasia at the Aptian (e.g. Sibuet et al. 2004; Vissers \& Meijer 2012a,b). An alternative scenario also combines a complex 


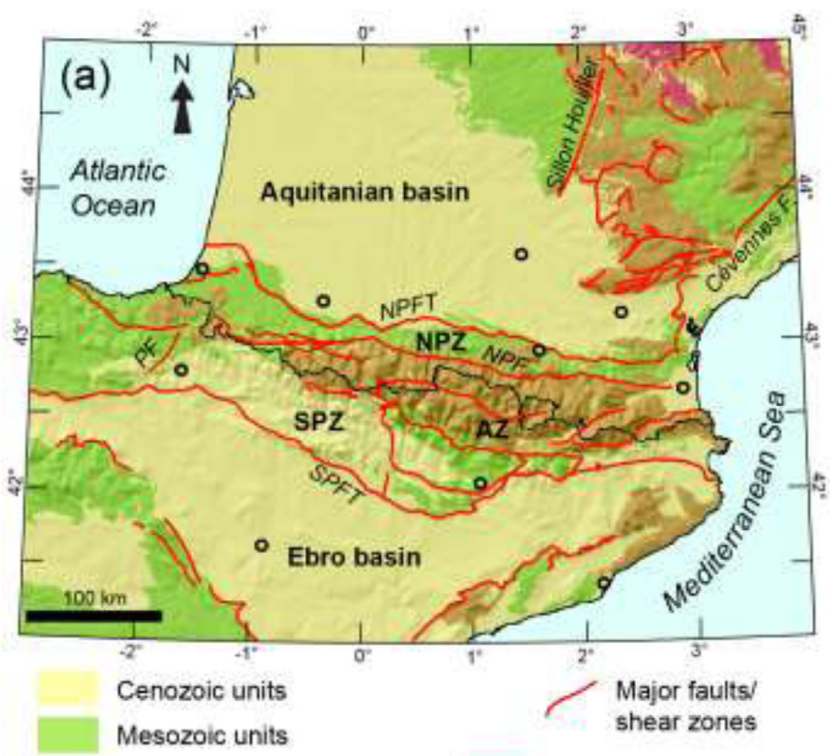

Paleozoic / Variscan units

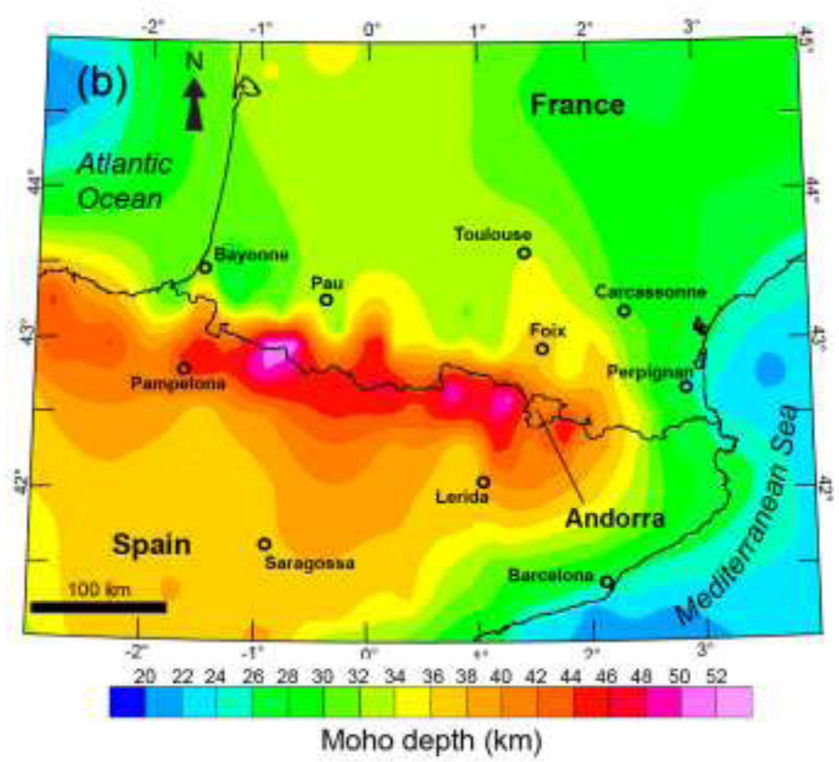

Figure 1. (a) Simplified tectonic map of the Pyrenees (modified from Mouthereau et al. 2014); SPZ: South Pyrenean Zone; SPFT: South Pyrenean Frontal Thrust; AZ: Axial Zone; NPZ: North Pyrenean Zone; NPFT: North Pyrenean Frontal Thrust; NPF: North Pyrenean Fault; PF: Pamplona Fault. (b) Crustal thickness (i.e. Moho depth) modified from Chevrot et al. (2014).

evolution of strike-slip movement during the Jurassic-Early Aptian with orthogonal extension related to the opening of the Bay of Biscay (Jammes et al. 2009). Despite numerous geophysical studies performed during the last decades to image the Pyrenean lithosphere (e.g. Gallart et al. 1980, 1981; Hirn et al. 1980; Daignières et al. 1981,1982; ECORS Pyrenees group 1988; Choukroune 1989; Roure et al. 1989; Torné et al. 1989; Choukroune et al. 1990; Nolet 1990; Daignières et al. 1994; Corchete et al. 1995; Souriau \& Granet 1995; Pous et al. 1997; Vacher \& Souriau 2001; Gunnell et al. 2008; Souriau et al. 2008; Carballo et al. 2014; Chevrot et al. 2014; Macquet et al. 2014; Wang et al. 2016; Bonnin et al. 2017; Martin et al. 2017; see also Section 2Contract Rep.), the deep structure of the Pyrenees remains uncertain. For example, the depth of the lithosphere-asthenosphere boundary beneath the
Pyrenees ranges from $\mathrm{ca}$. 90 to $160 \mathrm{~km}$ depending on authors and techniques employed (Zeyen \& Fernandez 1994; Pous et al. 1997; Roca et al. 2004; Gunnell et al. 2008; Campanyà et al. 2012; Carballo et al. 2014). A better knowledge of the deep structure of the Pyrenees will provide key constraints to improve our understanding of the Pyrenean geodynamics. During the PYROPE and IBERARRAY experiments, conducted respectively in France and Spain, 130 broad-band stations and two dense profiles of medium band seismic stations were deployed across the Pyrenees (2009-2013). The resulting tomographic images (Chevrot et al. 2014) exclude scenarios involving subduction of an oceanic lithosphere beneath the Pyrenees and suggest an along-strike segmentation of the lithospheric structure.

Geophysical data are frequently combined in cooperative studies in order to bring more constraint to the knowledge of the lithospheric structures, especially in orogens where interactions between various processes often lead to complex lithospheric structures. In particular, gravity data are often combined with other data sets to constrain lithospheric structures. Carballo et al. (2014) used elevation, geoid height and surface heat flow with gravity anomaly to model the lithospheric structure from the Pyrenees to the Tell Atlas Mountains in Algeria. Vacher \& Souriau (2001) built a 3-D lithospheric-scale density model of the Pyrenees and showed that Bouguer anomalies constrained by seismic images and petrology provide valuable information on the deep structure of an orogen. Furthermore, recent geophysical studies (Wang et al. 2016; Martin et al. 2017) have demonstrated the potential of seismic and gravity data to image crustal and lithospheric structures in the Pyrenees.

In addition to the recent PYROPE and IBERARRAY experiments, during the last several decades thousands of gravity stations were acquired in the Pyrenees and surrounding basins and compiled by the International Gravimetric Bureau (BGI: http: //bgi.obs-mip.fr/; Fig. 2a). In parallel, supported by the International Gravimetric Bureau, new gravity stations were acquired to complete the gravity cover of the eastern Pyrenees in France.

We propose here to combine all available gravity and recent seismic data acquired during PYROPE and IBERARRAY experiments in a joint inversion in order to reconsider the problem of imaging the deep lithosphere and upper-mantle structures of the Pyrenees. This joint inversion leads to a new density and velocity model of the deep structure of the Pyrenees that will complete and validate geological interpretations of previous regional tomography models (Souriau et al. 2008; Chevrot et al. 2014). The inversion method of ground gravity measurements and teleseismic delay times is based on the work of Zeyen \& Achaueur (1997), later improved by a 3-D ray tracing and independent density and velocity model parameterization (Tiberi et al. 2003). We then compare our results with previous geophysical models and discuss them in terms of tectonic processes involved in the Pyrenees formation.

\section{TECTONIC AND GEOPHYSICAL FRA ME W O R K}

The Pyrenees orogen (Fig. 1a) is composed of (i) the North Pyrenean Zone, corresponding to the retro-wedge dominated by Mesozoic sediments containing Palaeozoic basement; (ii) the Axial Zone, mostly located in the central Pyrenees and composed of Palaeozoic rocks, intensely deformed, metamorphosed and intruded by large granitic domes during the Variscan orogeny and then deformed during Alpine orogeny. The North Pyrenean Zone and the Axial Zone are separated by the North Pyrenean Fault (NPF; Fig. 1a) along part 


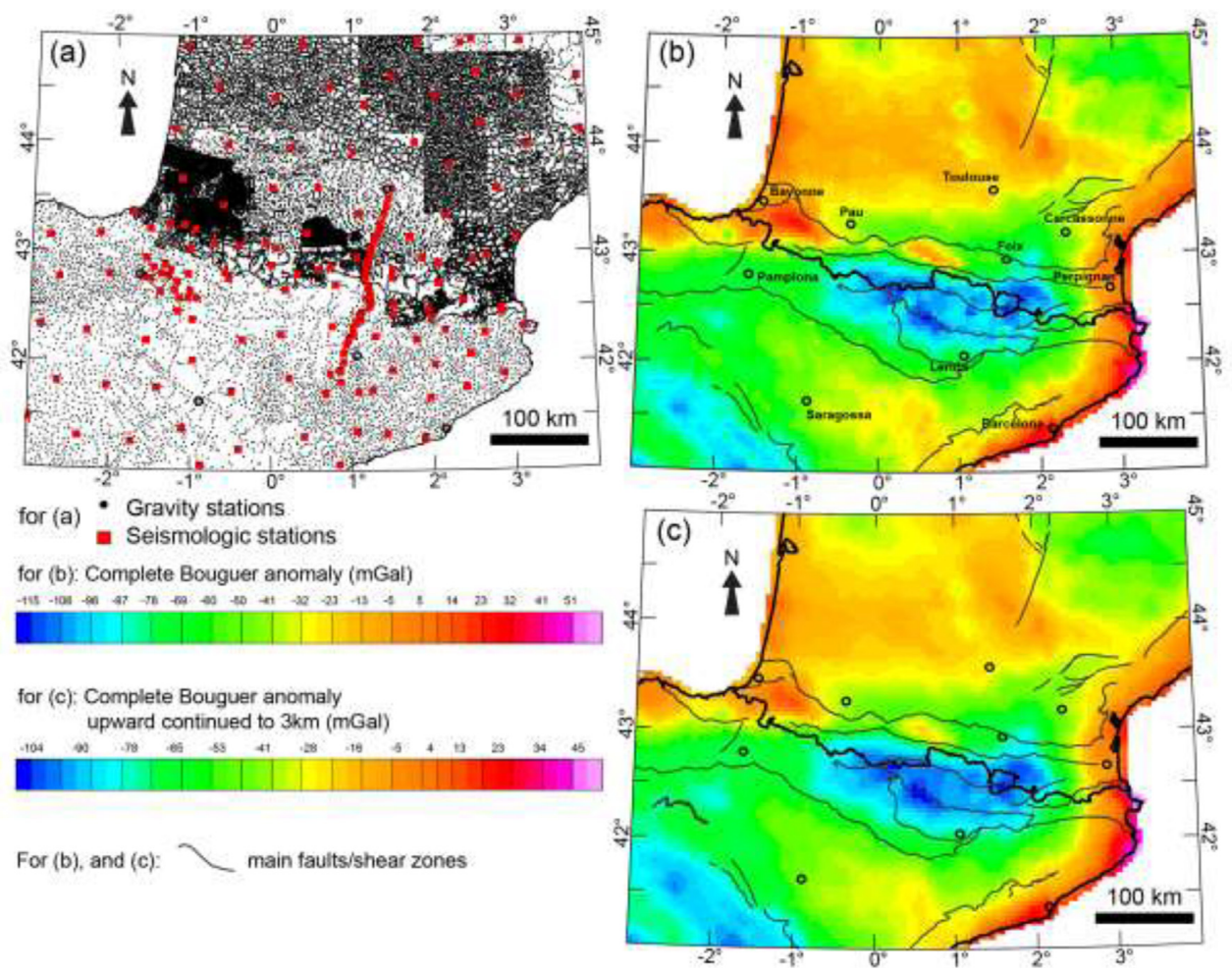

Figure 2. (a) Location of the gravity stations (source: Bureau Gravimétrique International) and seismologic stations (source: PYROPE project; Chevrot et al. 2014) used for joint inversion. (b) Map of the complete Bouguer gravity anomaly. (c) Map of the complete Bouguer gravity anomaly upwards continued to $3 \mathrm{~km}$ used for joint inversion.

of their contact; and (iii) the South Pyrenean Zone (SPZ; Fig. 1a), which corresponds to the pro-wedge dominated by Mesozoic and Cenozoic sediments. At the north of the Pyrenees orogen, the Aquitanian foreland basin corresponds to a large retro-foreland basin separated from the North Pyrenean Zone by the North Pyrenean Frontal Thrust (NPFT; Fig. 1a). At the south of the Pyrenees orogen, the Ebro foreland basin (Fig. 1a) is overthrust by the South Pyrenean Zone along the South Pyrenean Frontal Thrust (SPFT; Fig. 1a).

The deep Pyrenean crustal structure was imaged by several seismic profiles transverse to the Pyrenean general trend including the ECORS Arzacq and ECORS Pyrenees seismic profiles in the western and central parts of the orogen and several long-range $P$ wave reflection profiles (Hirn et al. 1980, Daignières et al. 1981,1982; Gallart et al. 1981; Séguret \& Daignieres 1986; ECORS Pyrenees group 1988; Choukroune et al. 1990). These profiles have shown that the Pyrenees form an asymmetric double wedge structure displaying northward-directed thrust in France and southward-directed thrust in Spain above a north dipping slab of Iberian continental lithosphere. They have also evidenced an abrupt Moho jump, located $c a .30 \mathrm{~km}$ deep beneath the Aquitanian basin and going down to $50 \mathrm{~km}$ beneath northern Iberia (i.e. Moho step of $c a .20 \mathrm{~km}$; Fig. 1b). The Pyrenean Moho's jump decreases eastwards to reach its minimum (ca. $5 \mathrm{~km}$ ) in the eastern Pyrenees (Gallart et al. 1980; Chevrot et al. 2014; Mancilla \& Diaz 2015). Gravity modelling performed along the ECORS profiles also confirmed the asymmetrical shape of the Pyrenean crust (Torné et al. 1989). Ledo et al. (2000), from a 3-D electrical conductivity model of the Pyrenean lithosphere, identified a high conductivity zone in the lower crust interpreted as partial melting of the subducted Iberian lower crust. Two teleseismic $P$-to- $S$ converted waves were performed along two dense transects across the central and western Pyrenees (Chevrot et al. 2015). They support the previous interpretation of the ECORS Arzacq profile proposed by Teixell (1998) and suggest the subduction of thinned Iberian crust down to $c a .70 \mathrm{~km}$. More recently, Wang et al. (2016) presented a 3-D velocity model of the lithosphere beneath the western Pyrenees from full waveform inversion of teleseismic $P$ waves confirming the emplacement of subcontinental mantle at shallow crustal levels beneath the Mauléon basin. Souriau et al. (2008) used teleseismic P and PKP traveltime to provide a new tomographic model of the Pyrenean lithosphere down to $200 \mathrm{~km}$. They identified a high-velocity zone in the easterncentral Pyrenees interpreted as a detached portion of the Tethys slab and suggested the presence of Variscan NW-trending low-velocity structures. However, Chevrot et al. (2014) stated that this study suffered from a poor quality of manual picks and small N-S aperture of the seismological array that limit the resolution of the deeper parts of the model. Chevrot et al. (2014) exploited the newly acquired seismic data of PYROPE and IBERARRAY experiments to obtain a new tomographic model of SW Europe from the Massif Central to central Iberia. They exclude scenarios involving subduction of oceanic lithosphere beneath the Pyrenees and suggest an along-strike segmentation of the lithosphere by transverse structure oriented NNW-SSE. The lithospheric structure of the Pyrenees and adjacent basins deduced from ambient noise tomography evidences two unusual velocity structures. The first one is located beneath the SE part of the Massif Central associated with a shallow Moho, and the second in the central Pyrenees shows the presence of Iberian crust underthrust beneath the Eurasian crust (Macquet et al. 2014). 


\section{METHODOLOGY}

\subsection{Data}

\subsubsection{Gravity data}

The Gravity cover of the study area includes 62065 ground measurements provided by the Bureau Gravimétrique International (Fig. 2a). In this data set, 332 new stations were acquired in the eastern part of the Pyrenees by Géosciences Environnement Toulouse and Géosciences Montpellier laboratories with the support of the $\mathrm{Bu}-$ reau Gravimétrique International using a CG5 Scintrex gravimeter (1 $\mu \mathrm{Gal}$ resolution, $<5 \mu \mathrm{Gal}$ repeatability). The distribution of gravity data in the study area is inhomogeneous, with a variable station spacing generally less than $1 \mathrm{~km}$, except in the central part of the Pyrenees where high relief hampered data acquisition. Freeair and Bouguer corrections were calculated using the International Association of Geodesy 1967 formula. An average density of $2.67 \mathrm{~g}$ $\mathrm{cm}^{-3}$ is used to correct from the topographic effect. The complete Bouguer correction was performed by applying a ground correction derived from $90 \mathrm{~m}$ resolution digital elevation model (SRTM90) using Gravsoft software (Forsberg \& Tscherning 2008) with a radius of inner and outer zones of $100 \mathrm{~km}$. We performed a slight upward continuation of the data of $3 \mathrm{~km}$ using Geosoft Oasis Montaj in order to be above the causative sources of our density model and to be consistent with the joint parametrization (see the following section). We filtered the gravity data to limit the effect of surficial short wavelength structures, not modelled in our lithospheric imaging. We gridded the resulting complete Bouguer anomaly (Fig. 2b) and $3 \mathrm{~km}$ upward continued complete Bouguer anomaly (Fig. 2c) on $5 \mathrm{~km}$ grid maps with a minimum curvature algorithm (Briggs 1974). We finally used the resulting upward continued complete Bouguer anomaly grid (62 065 points, Fig. 2c) in the joint inversion.

As portrayed by Casas et al. (1997), the Pyrenees are associated with a large negative anomaly (i.e. from $c a$. -120 to $-90 \mathrm{mGal}$; Figs $2 b$ and c) mainly located in Spain and caused by the thick Pyrenean crustal roots (Fig. 1b). The eastern termination of this negative anomaly occurs at the east of Andorra and corresponds to the eastward thinning of the Pyrenean crust (Fig. 1b). A slight northeastward continuation of this negative anomaly occurs in France (NW of Andorra; Fig. 2b) and corresponds to a local thicker continental crust (Fig. 1b). The western termination of the Pyrenean negative anomaly broadly corresponds to the westward disappearance of outcrops of Palaeozoic units in the Axial Zone. Note that the deepest Moho located in the western part of the Pyrenees determined from receiver function (Chevrot et al. 2014; Mancilla \& Diaz 2015) is not encompassed within the main negative anomaly caused by crustal thickening (Figs $1 \mathrm{~b}$ and $2 \mathrm{~b}$ and c). The Aquitanian and Ebro basins are roughly associated with a higher gravity response than surrounding domains, respectively ranging from $c a$. -20 to $5 \mathrm{mGal}$ and $c a$. -35 to $-20 \mathrm{mGal}$, materializing the sedimentary filling within the basins. The North Pyrenean Zone and the South Pyrenean Zone are dominated by a gravity response of $c a$. $-50 \mathrm{mGal}$. The Labourd and Saint-Gaudens positive gravity anomalies clearly visible on the Bouguer gravity map (Fig. 2a) were explained by the emplacement of high density body at upper crustal level (Grandjean 1994; Corpel \& Casas 1996; Pedreira et al. 2007). The Labourd gravity anomaly is also interpreted by the emplacement of mantle material within the crust (Wang et al. 2016). These crustal anomalies were previously imaged by gravity data (Grandjean 1994), seismic crustal tomography (Souriau \& Granet 1995; Souriau et al. 2008) and ambient noise surface waves (Villaseñor et al. 2007). In the NE of the study area, the southern Massif Central is associated with low gravity anomaly ranging from $c a$. -60 to $-30 \mathrm{mGal}$.

\subsubsection{Traveltime data}

The teleseismic $\mathrm{P}$ traveltime residuals used in this study were previously compiled and used in Chevrot et al. (2014). They come from the temporary PYROPE (http://dx.doi.org/10.15778/RESIF.X720 10) and IBERARRAY experiments (https://doi.org/10.7914/SN/IB) (broad-band stations, Fig. 2a). Data from the permanent broadband stations of the Réseau Large Bande Permanent (RLBP; http://rlbp.unistra.fr), the short-period stations of the Réseau National de Surveillance Sismique (RéNaSS; http://renass.unistra.fr) on the French side, the permanent broad-band stations of the Instituto Geográfico Nacional (IGN; http://www.ign.es) and of the Institut Cartogràfic i Geòlogic de Catalunya (ICGC; http://www.icgc.cat) in the Pyrenees and surrounding domain were also added (Chevrot et al. 2014). We used $P$ wave traveltimes from 162 teleseismic events with a moment magnitude larger than 5.8 and recorded between January 2008 and September 2013 in the epicentral distance range $30^{\circ}-90^{\circ}$ (Fig. 3). The traveltime residuals are calculated by subtracting the theoretical traveltime computed in the ak135 reference earth model as described in Chevrot et al. (2014). For each event, the mean residual was then removed to obtain relative time residuals and get rid of common errors resulting from source mislocation and uncertainty on the origin time. The obtained data set is composed of 2851 relative traveltime residuals over the whole network (166 stations).

\subsection{Joint inversion of gravity and delay times}

\subsubsection{Joint inversion scheme}

The joint inversion method used in this study was introduced by Zeyen \& Achauer (1997) and then further modified by Tiberi et al. (2003). It has been successfully applied in various geodynamical settings (Tiberi et al. 2003; Tiberi et al. 2008; Basuyau \& Tiberi 2011; Basuyau et al. 2013). This method is based on the coherent behaviour and the approximate linear relationship between $P$-wave velocity and density perturbations (Birch 1961; Abers 1994):

$\Delta V \mathrm{p}=B . \Delta \rho$,

where $B$ is a coefficient depending on rock type and mostly ranges from 2.5 to $3.5 \mathrm{~km} \mathrm{~s}^{-1} \mathrm{~g}^{-1} \mathrm{~cm}^{3}$ (Birch 1961).

Three unknown parameters are considered in the inversion process: (i) the $P$-wave velocity anomaly $(\Delta V \mathrm{p} / V \mathrm{p})$; (ii) the density contrast $(\Delta \rho)$; (iii) the $B$ coefficient. The joint inversion is based on a Bayesian approach requiring a priori 3 -D velocity and density models in order to reduce the set of possible solutions.

The method starts with those a priori models (see the next section) and iteratively modifies them to jointly minimize the Bouguer gravity anomaly and traveltime residuals in a least-squares sense. We performed an optimization algorithm that invokes three steps for each iteration:

(1) The gravity forward calculation is performed at iteration $n$ by applying Blakely (1995) forward method on the density contrasts obtained at iteration $n-1$. We compute the delay times at iteration $n$ using the bending method of Steck \& Prothero (1991). The seismic rays are propagated in the 3 -D velocity model obtained at iteration $n$ -1 . The $B$ coefficient is computed based on the correlation between density and velocity $n-1$ models. 


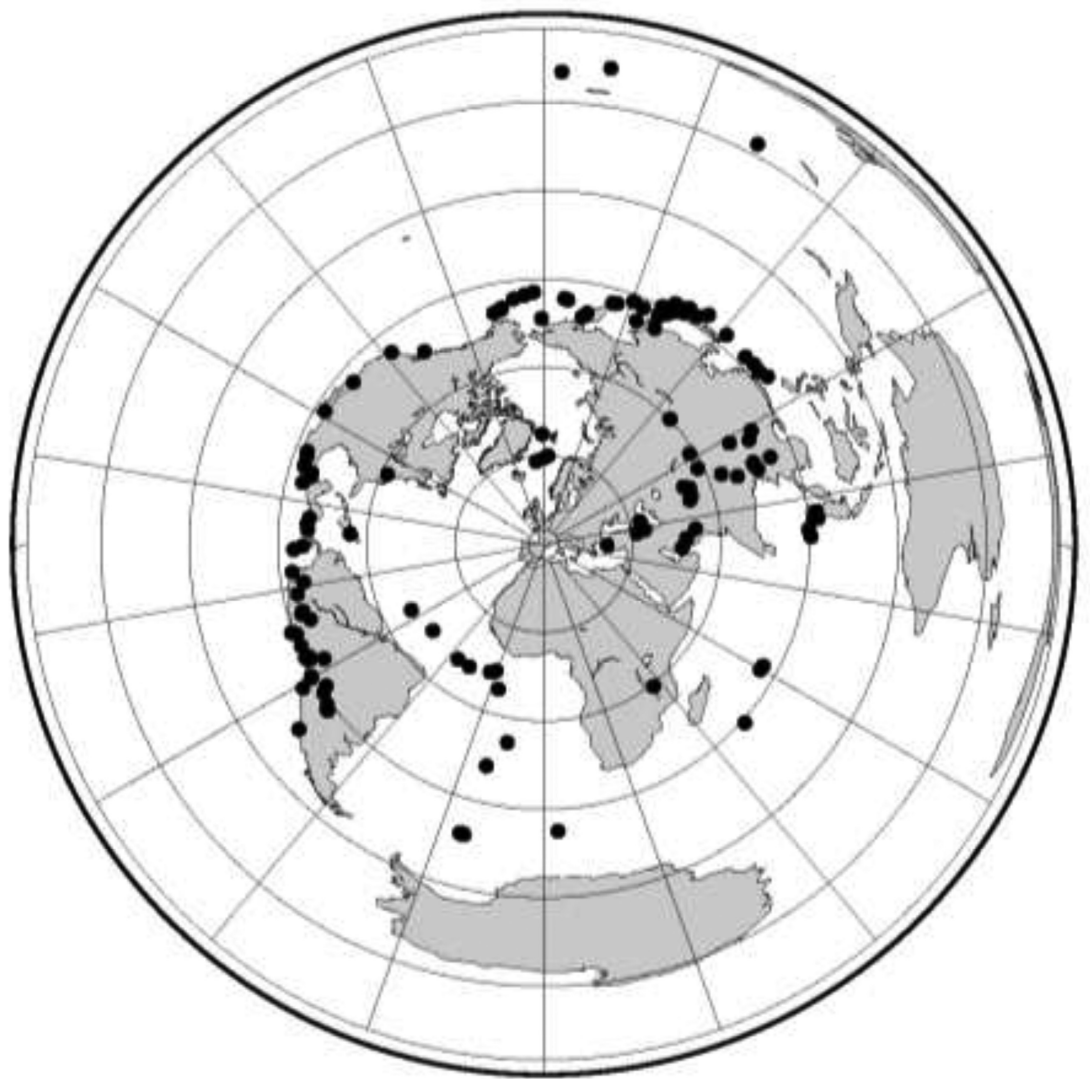

Figure 3. Azimuthal distribution of the first $P$-wave teleseismic events used for this study $(M>5.8, \mathrm{AZ}=[25-100])$. The projection is centred on the Pyrenees.

(2) The delay times and gravity anomaly for iteration $n$ are then compared to the observed data, and new residuals are computed.

(3) The new residuals are finally inverted in the least-squares sense to obtain a new density and velocity perturbation distribution. These new density and velocity models become the starting models for iteration $n+1$.

This inversion scheme is iterated until it reaches a pre-defined number of iterations or when the observed and calculated data difference falls below a given threshold. We estimate the success of the inversion through the root mean square (rms) reduction, final standard deviation of parameters and recovered data, and synthetic tests. Readers can refer to Tiberi et al. $(2003,2008)$ for further details on the joint inversion scheme.

\subsubsection{Model parameterization}

The inversion requires one model for density and one for velocity. They are both discretized into $N$ layers. Each layer is subdivided into rectangular blocks to which a density contrast is assigned (Blakely 1995). Each density block contains a velocity node to fulfil the formalism of Steck \& Prothero (1991) and to warrant a good estimation of $B$ value in each layer. Between those nodes, the velocity is interpolated with a gradient method (Thurber 1983). The density block dimension and the velocity node spacing are dictated by wavelength content of the gravity anomaly and by the seismic station coverage. It should also optimize the ratio between the number of model parameters and observed data. As the inversion problem is already ill-posed, we do not try to increase its inherent underestimation by having unconstrained density blocks and velocity nodes (e.g. Menke 1984).

We tested different nodes/blocks configuration, and horizontal and vertical extensions of the initial model to evaluate their influence on the final solution. We finally opted here for a regular $26 \times 23$ blocks/nodes parametrization. This regular gridding allows for a homogeneous a priori distribution of sources and for a better coherency between density and velocity anomalies' shape and size. The block dimension and node spacing are $25 \mathrm{~km}$ in east-west and north-south directions, except for the outermost edges, where larger blocks and node interval $(100 \mathrm{~km})$ were chosen to absorb the boundary effect. We divided our models into seven layers (Table 1). The first layer starts from $3 \mathrm{~km}$ of elevation down to $30 \mathrm{~km}$ depth to take into account the topography. The 3-D ray tracing starts from the seismic station elevation, so that even if not fully resolved because of poor ray crossing (Zeyen \& Achauer 1997), the velocity and density first layer contain consistent information and include topography.

A priori information is used during inversion to constrain the models, limit the effect of noise and reduce the impact of an ill-posed problem. First, initial standard deviations are assigned to both data and parameters. We set the standard deviations for gravity and delay times data to the estimated accuracy of gravity measurement and traveltime picks ( $c a .2 \mathrm{mGal}$ and $0.01 \mathrm{~s})$. From our tests, we decide to favour a homogeneous a priori constraint by settling constant standard deviations for density $\left(0.01 \mathrm{~g} \mathrm{~cm}^{-1}\right)$ and velocity $(0.01 \mathrm{~km}$ $\mathrm{s}^{-1}$ ). For density and velocity models, the a priori model values are based on the ak135 reference Earth model (Kennett et al. 1995) and 
Table 1. Parametrization of density and velocity initial models for the joint inversion. The velocity nodes are located at the centre of each density block. The correlation coefficient corresponds to the level of coherence between velocity and density at the end of the inversion.

\begin{tabular}{lcccc}
\hline Layer interfaces depth $(\mathrm{km})$ & Velocity initial $\left(\mathrm{km} \mathrm{s}^{-1}\right)$ & Density initial $\left(\mathrm{g} \mathrm{cm}^{-1}\right)$ & Final $B$ value & Correlation coefficient \\
\hline$-3^{*}$ to 30 & 6.15 & 2.67 & 3.726 & 0.684 \\
$30-60$ & 8.03 & 3.00 & 2.828 & 0.575 \\
$60-100$ & 8.04 & 3.30 & 3.223 & 0.417 \\
$100-150$ & 8.05 & 3.33 & 3.354 & 0.726 \\
$150-200$ & 8.2 & 3.35 & 3.420 & 0.900 \\
$200-250$ & 8.4 & 3.39 & 3.527 & 0.948 \\
$250-300$ & 8.5 & 3.50 & 056 \\
\hline
\end{tabular}

*The uppermost interface of the first layer is $3 \mathrm{~km}$ in elevation in order to include the topographic effect.

adapted to our own layering (Table 1). Initial value of $B$ was set to 3 for all layers. The maximum number of iterations was fixed to five.

We add a smoothing constraint to avoid sharp and strong oscillations between neighbouring density blocks or velocity nodes (Zeyen \& Achauer 1997). In order to choose the optimum smoothing parameters, we followed the L-curve method (see Hansen 2001; Foulger et al. 2013). We used the trade-off curves from a selection of models to investigate the balance between model roughness (quantified by the difference between the extreme positive and negative wave speed/density contrasts) and root mean square prediction error reduction (in per cent). We also tested initial standard deviation parameters. After all these tests, the smoothing density and velocity constraints are respectively set to 0.003 and 0.001 .

\subsubsection{Model resolution}

We estimate the resolution of our final model from different factors. First, the calculation of resolution matrix diagonal terms is performed at the end of the inversion process. The resolution matrix relates true and estimated models and should thus be close to identity to provide unbiased results (Menke 1984). Values of the diagonal terms are strongly dependent on the smoothing constraint (the smoother, the smaller terms). As expected, the resolution of inverted density parameters (Fig. 4) is larger in crustal layers (i.e. up to $60 \mathrm{~km}$ depth) with a maximum diagonal term of $c a .1 .0$ for the first layer. It then strongly decreases with depth (locally up to $c a .0 .8$ in the 30-60 km layer). The average resolution diagonal term for velocity parameters is $c a$. 0.3 , with values up to 0.6 locally (Fig. 5). The best resolution is unsurprisingly obtained in the central part of the study area, beneath the Axial Zone and the North Pyrenean Zone (see Fig. 1a) where ray crossing and coverage are the highest. The best resolved depth interval is between 100 and $200 \mathrm{~km}$ (Fig. 5), similar to Chevrot et al. (2014). Second, to evaluate the linear resolving power of the inversion, we test the ability of our data sets to retrieve a checkerboard model in the lithosphere and asthenosphere. This classic approach allows to (i) define areas that are well constrained, (ii) estimate the vertical smearing along the subvertical teleseismic rays, and (iii) assess the shortest anomaly wavelength that can be retrieved from our ray coverage. The number and size of layers, the velocity nodes and the gravity blocks are similar to the initial model presented in Table 1 . We alternate positive and negative perturbations in layers $2(30-60 \mathrm{~km}$, i.e. lithosphere/subcrustal perturbations) and 5 (150-200 km, i.e. asthenosphere perturbations). The perturbations of the checkerboard pattern size are $[3 \times 3]$ density blocks and velocity nodes, and their amplitude is \pm 5 per cent relative to the a priori density and velocity model (Figs 6 and 7). These synthetic structures with identical model parameterization were jointly inverted using the real data distribution. The resulting density and velocity models are presented in Figs 6 and 7. Narrower synthetic anomalies within a $[2 \times 2]$ density blocks and velocity nodes checkerboard pattern were also tested. Density and velocity blocks were correctly recovered in the layer 30-60 km, but velocity nodes were inadequately resolved deeper, even in the middle of the model where the best resolution is expected. Finally, we also estimate the smearing effect and lateral resolution with a spike test of three smaller perturbations sizing $[2 \times 2]$ density blocks and velocity nodes with an amplitude of \pm 5 per cent relative to the $a$ priori density and velocity model in the layer 30-60 km (Figs 8 and 9).

The size and shape of the recovered velocity checkerboard confirm the ability of the inversion process to retrieve perturbations at lithospheric and asthenospheric level, as well as its capacity to resolve lateral contrasts (Figs 7 and 9). As expected in such teleseismic tomography, vertical smearing is present and affects the layers above and below the input anomalies (Foulger et al. 2013). The amplitude of the initial velocity perturbation is thus distributed in three layers, and is consequently reduced in the original one (at 30-60 or 150 $200 \mathrm{~km}$ ). The checkerboard size and shape of the density anomaly is well retrieved in layer 30-60 km (Fig. 6), highlighting the good lateral resolution of the density for crustal/lithospheric depth (30 to $60 \mathrm{~km}$ ) consistent with the model resolution (Fig. 4). Similarly to the velocity model, but to a lesser extent, the checkerboard pattern in layer $30-60 \mathrm{~km}$ is smeared down to $100 \mathrm{~km}$ depth. The geometry of the checkerboard pattern at $150 \mathrm{~km}$ is weakly distinguishable, limited by the poor vertical resolution of the density model. The decrease in resolution observed in the Ebro basin (Spanish part) can be explained by the lack of southeast teleseismic events, which prevent us from retrieving more complete information on the structures in that region (Fig. 3).

Finally, the good convergence of the inversion is estimated from the decrease of the rms through five iterations. The gravity residuals decrease from 22.57 to $2.03 \mathrm{mGal}$ ( 90.99 per cent) and the delay time residuals decrease from 0.37 to $0.2 \mathrm{~s}$ ( 47.88 per cent; Fig. 10). These results are broadly comparable to the rms decrease obtained in previous studies in the Pyrenees, Central Mongolia and Southern Siberia for gravity data (94 per cent, Tiberi et al. 2008) and delay times (43 per cent, Tiberi et al. 2008; ca. 70 per cent Chevrot et al. 2014) attesting the stability and robustness of the inversion. The final density and velocity variations in our models range, respectively, between -0.2 and $+0.2 \mathrm{~g} \mathrm{~cm}^{-3}$ and -3 and +3 per cent indicating reasonable values for lithospheric scale. The complete Bouguer anomaly calculated from our density model is broadly consistent with the observed complete Bouguer anomalies attesting for the accuracy of our density model (Figs 11a and b). The highest discrepancies happen for the central part of the Pyrenees, where our inversion slightly overestimates the gravity signal (Fig. 11c).

The coherence between velocity and density contrast can be estimated through the $B$ value evolution. As the joint inversion scheme 

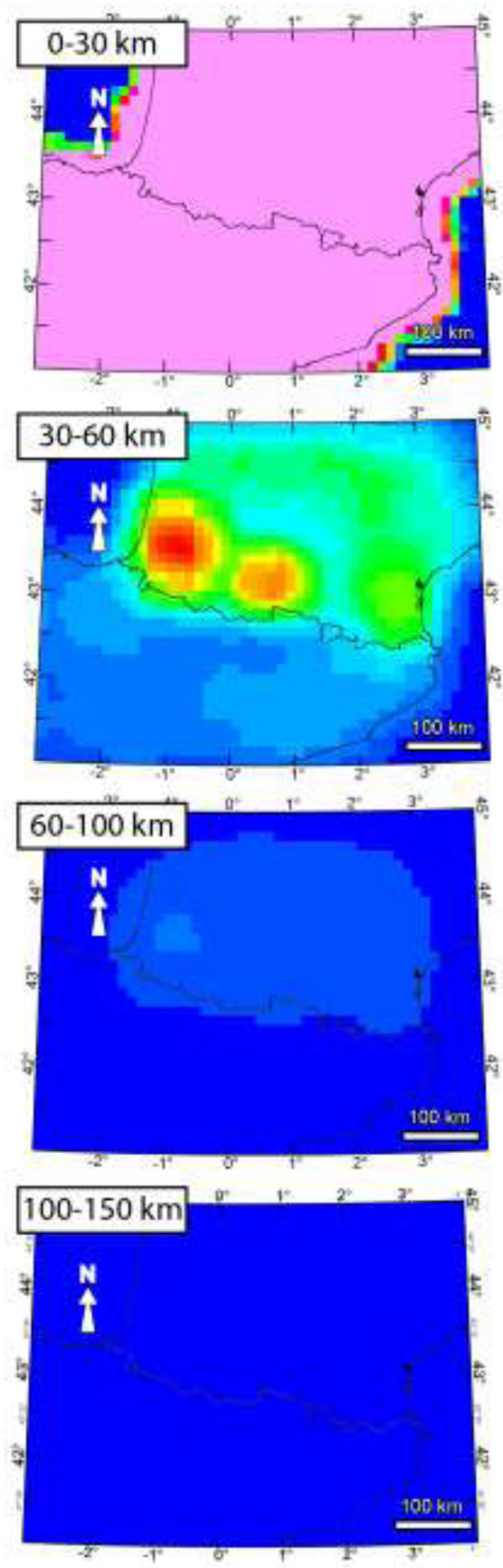

Figure 4. Lateral resolution in the density model.

is highly non-linear, we have to restrict the variation of this parameter in a reasonable range (i.e. $<5 \mathrm{~km} \mathrm{~s}^{-1} \mathrm{~g}^{-1} \mathrm{~cm}^{3}$ ). The final $B$ values and the associated correlation coefficients obtained after five iterations are listed in Table 1 . The lowest values are unsurprisingly
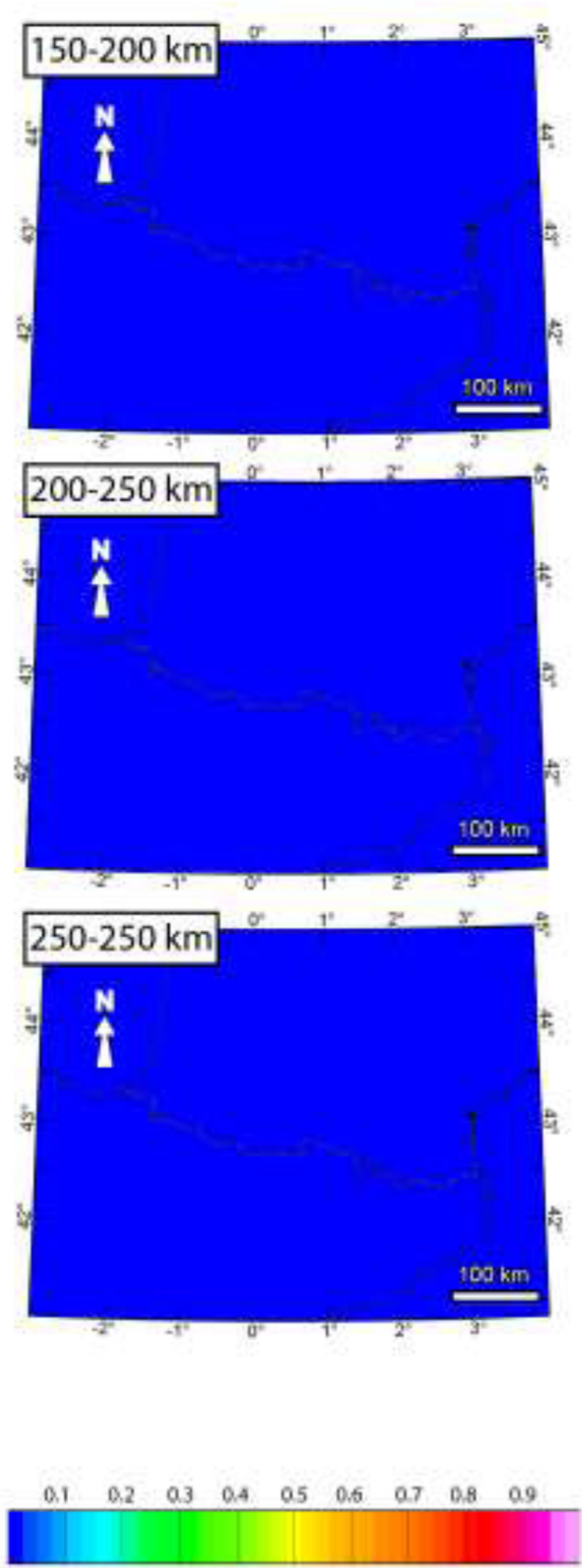

Density resolution

obtained for the second layers (30-60 km), where shortest wavelengths in gravity signal and lowest resolution in seismology result in a low correlation. Moreover, our single average $B$ value for one whole layer can hardly reflect the geological heterogeneity of the 

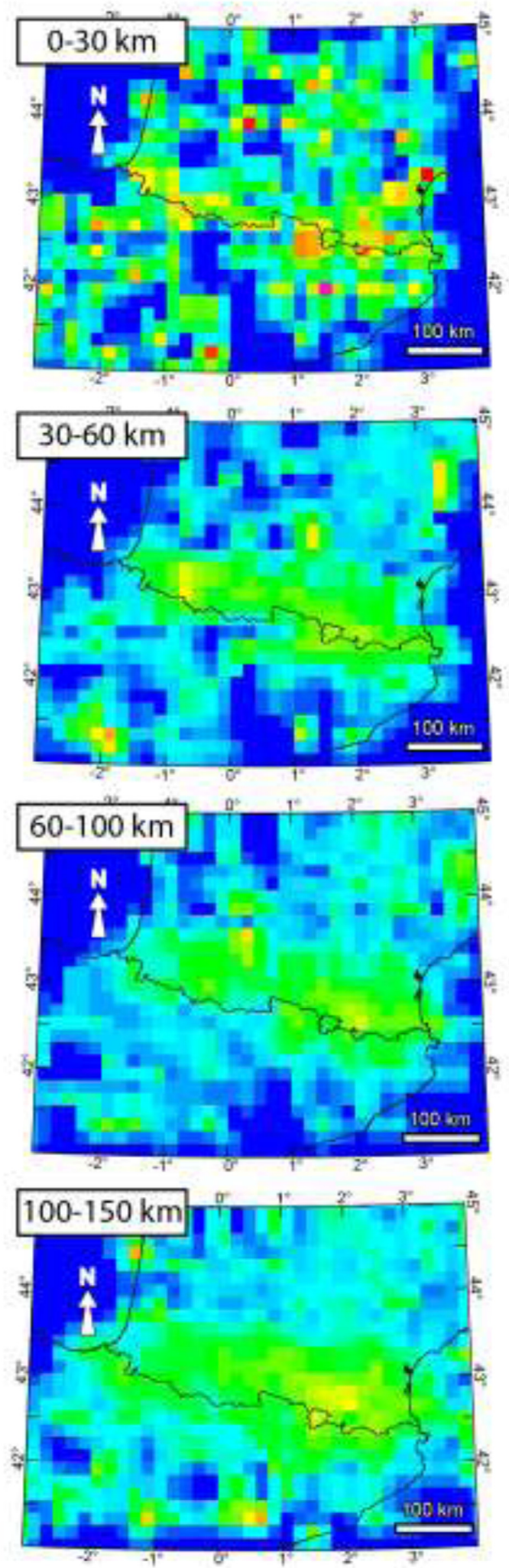

Figure 5. Lateral resolution in the velocity model.

region, and we reach a limit of this inversion. Basuyau et al. (2013) also obtained a smaller $B$ value than expected in a $c a .40 \mathrm{~km}$ deep layer, and it may reflect the bad correlation of density and velocity at this depth interval. For the deep lithosphere $(60-100 \mathrm{~km})$ and
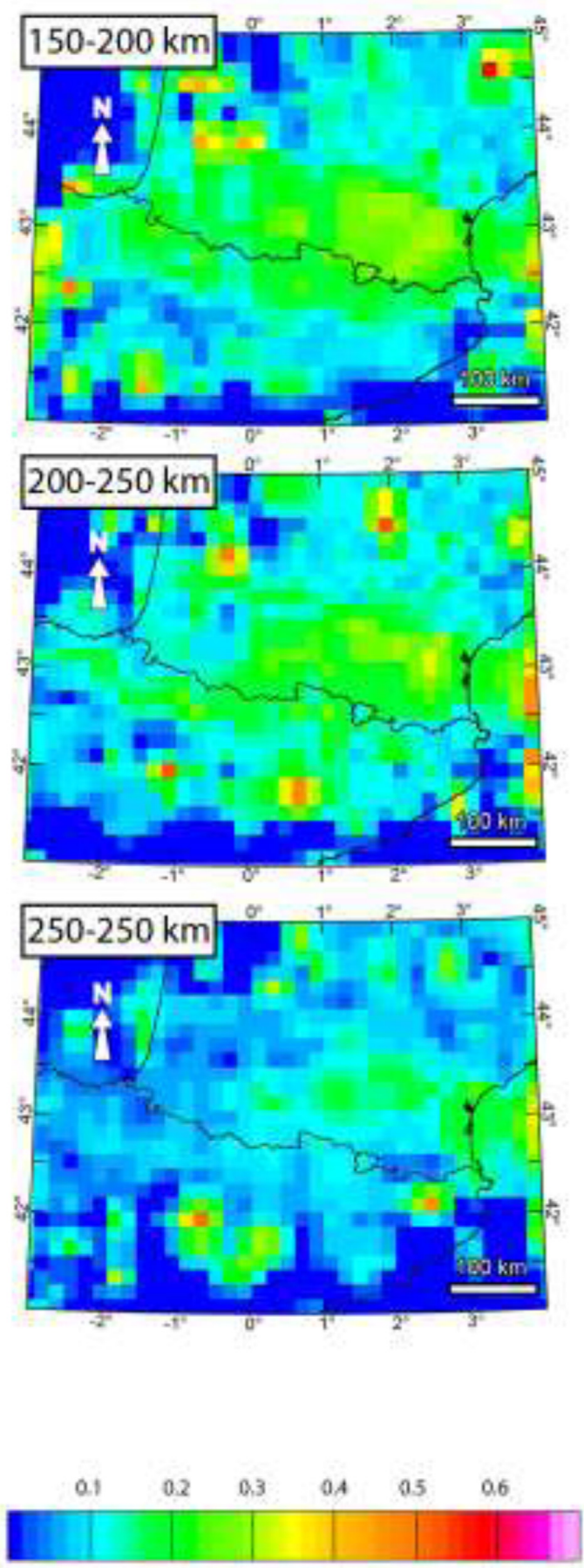

Velocity resolution

the mantle layers (beneath $100 \mathrm{~km}$ ), the $B$ value is stable $(c a .3 \mathrm{~km}$ $\mathrm{s}^{-1} \mathrm{~g}^{-1} \mathrm{~cm}^{3}$ ) indicating a good compatibility of velocity and density variation within these layers. 

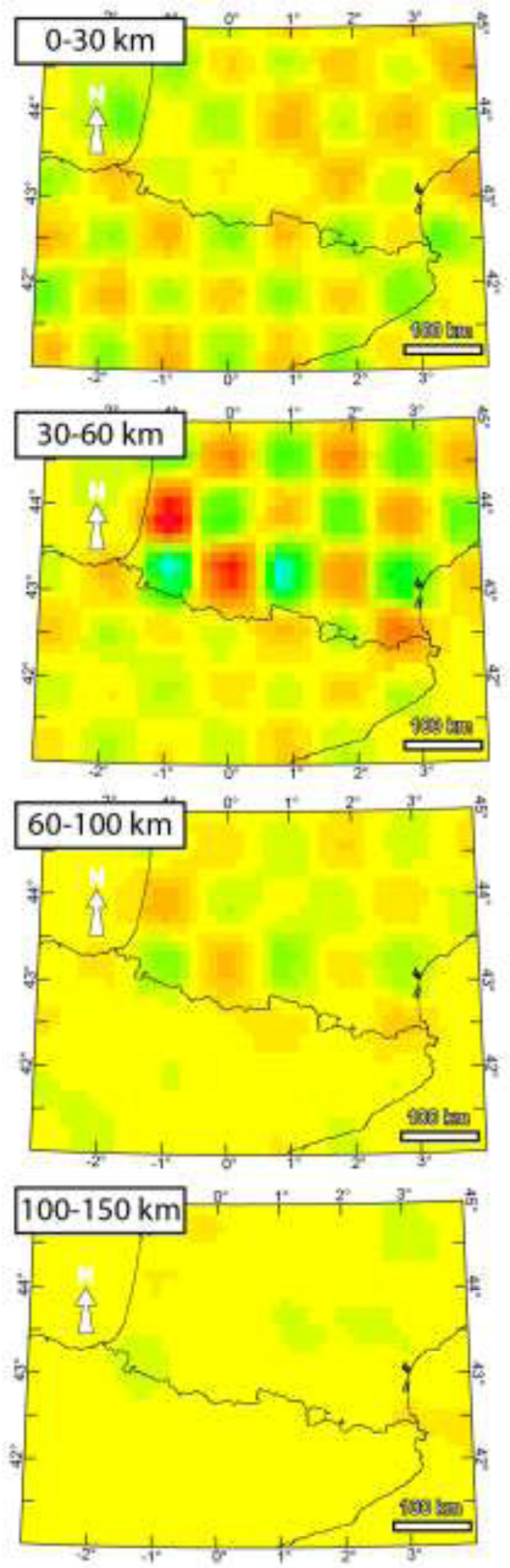
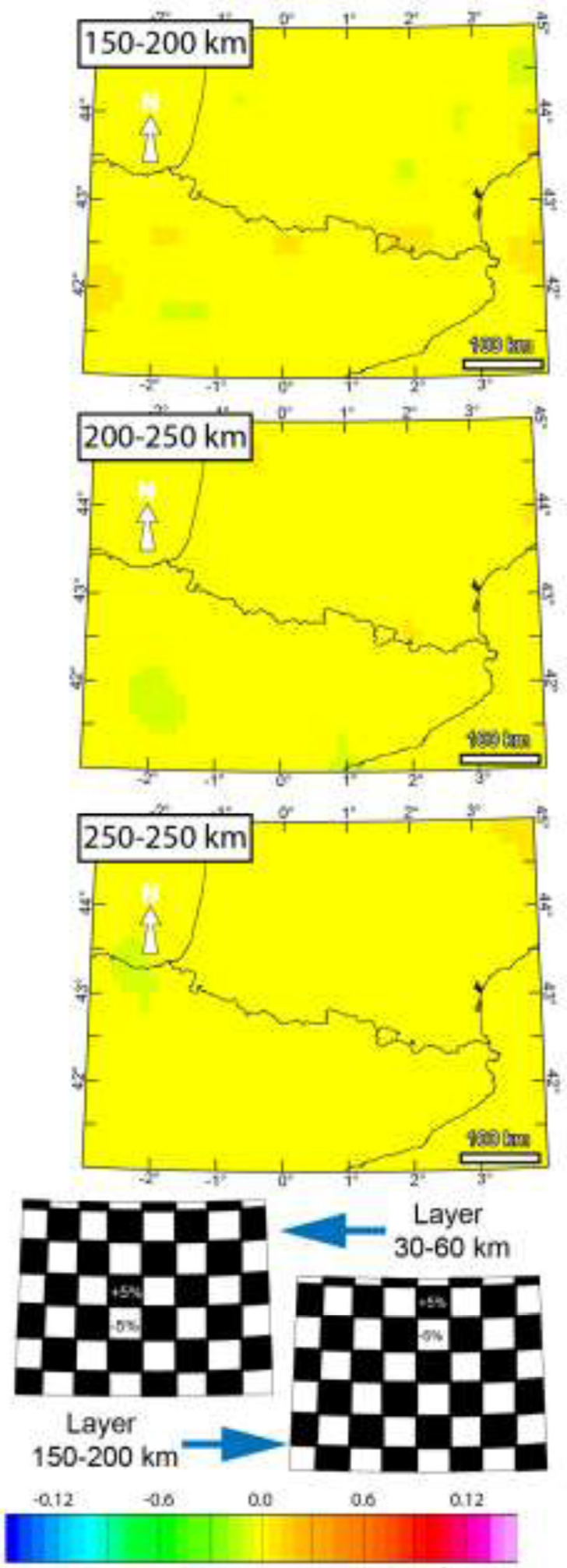

\section{Density perturbation $\left(\mathrm{g} \cdot \mathrm{cm}^{3}\right)$}

Figure 6. Output synthetic checkerboard test for density model. The input density contrasts are \pm 0.5 per cent of the initial density model (Table 1 ) and are located in layers $30-60$ and $150-200 \mathrm{~km}$. 

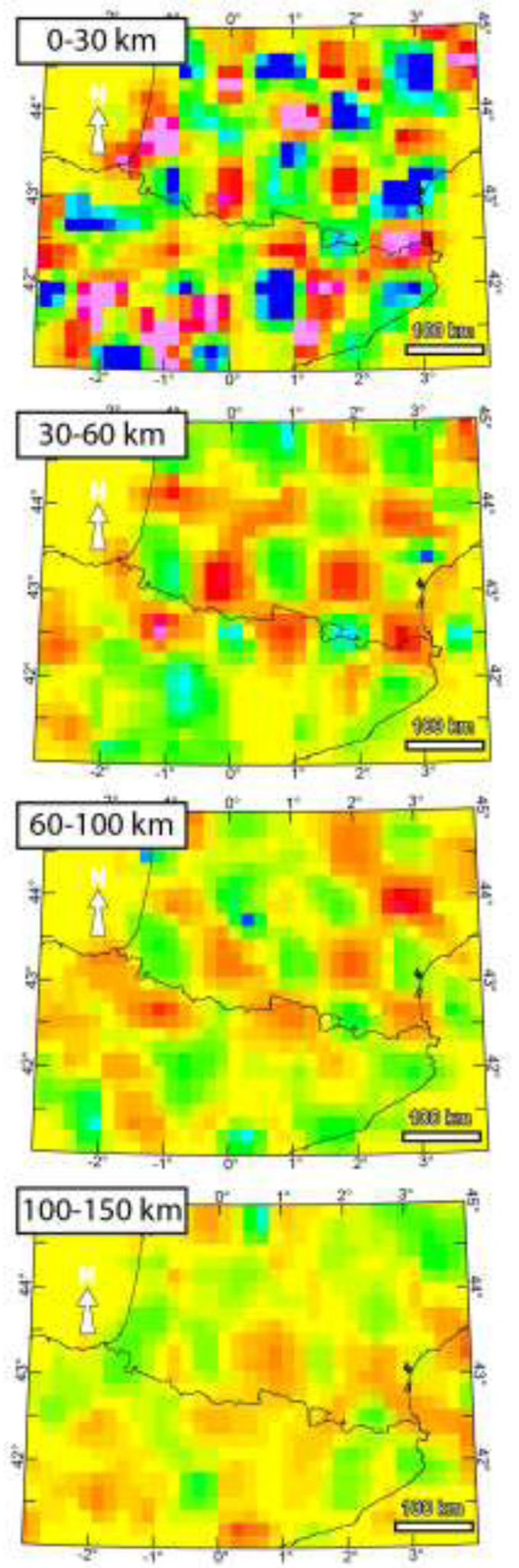
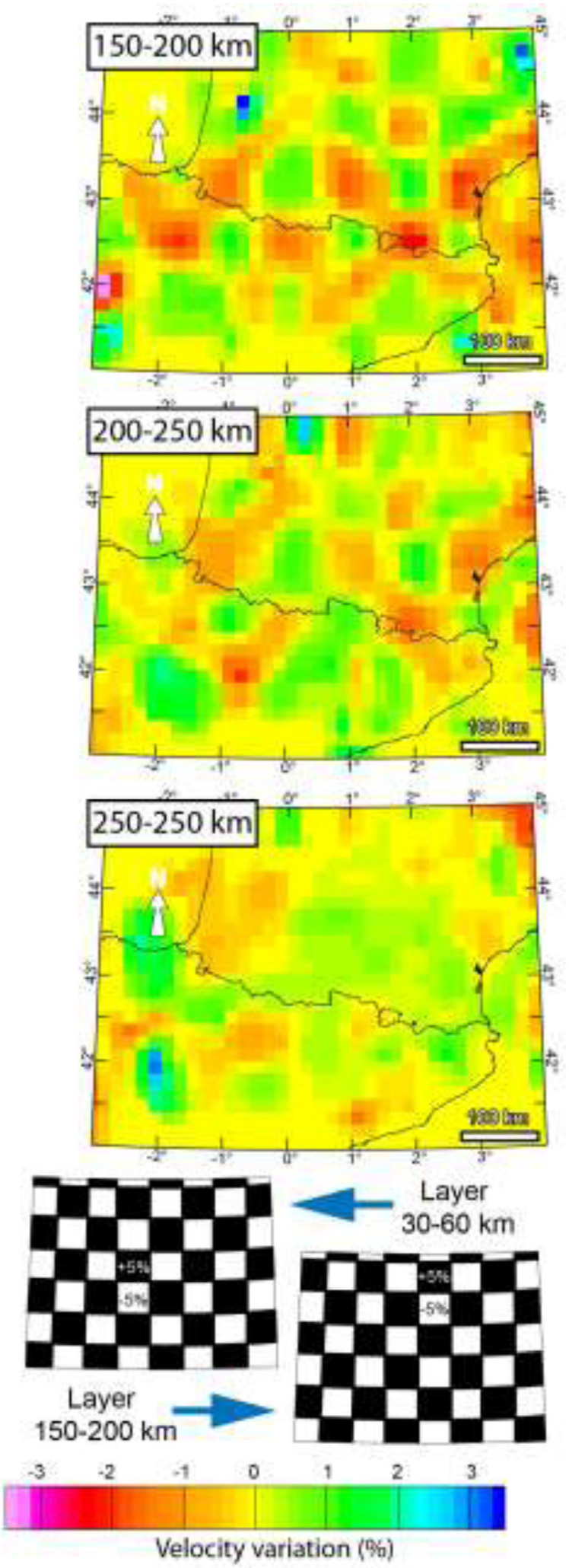

Figure 7. Output synthetic checkerboard test for velocity model. The input velocity contrasts are \pm 0.5 per cent of the initial velocity (Table 1 ) and are located in layers $30-60$ and $150-200 \mathrm{~km}$. 

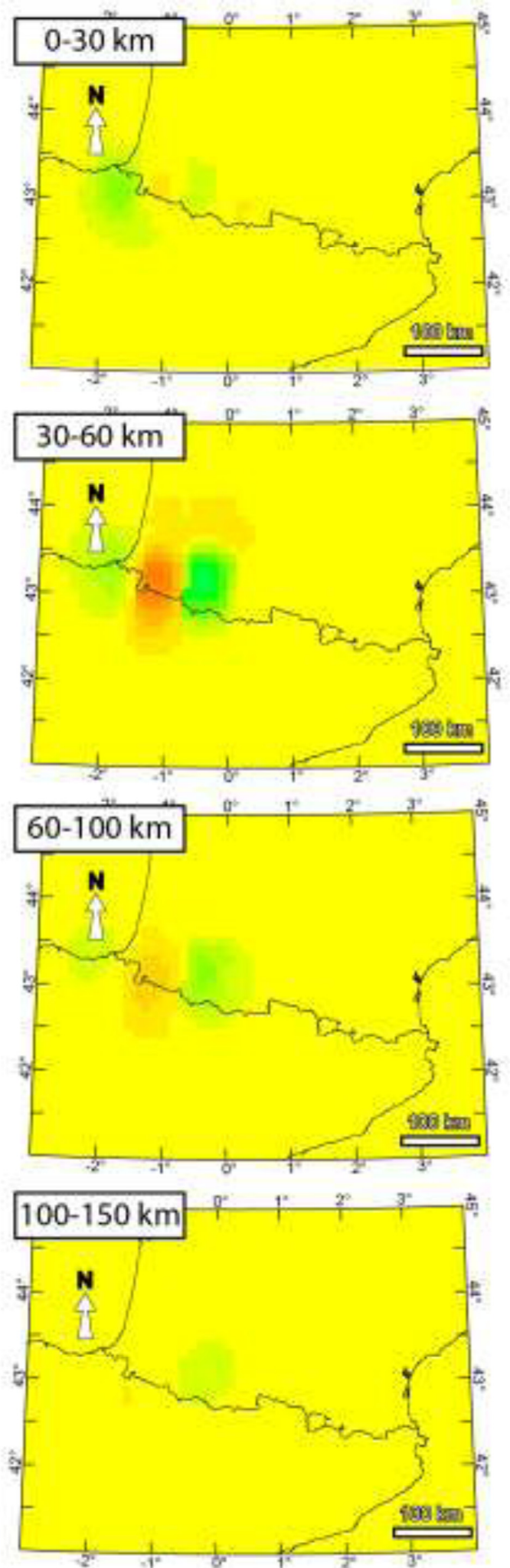
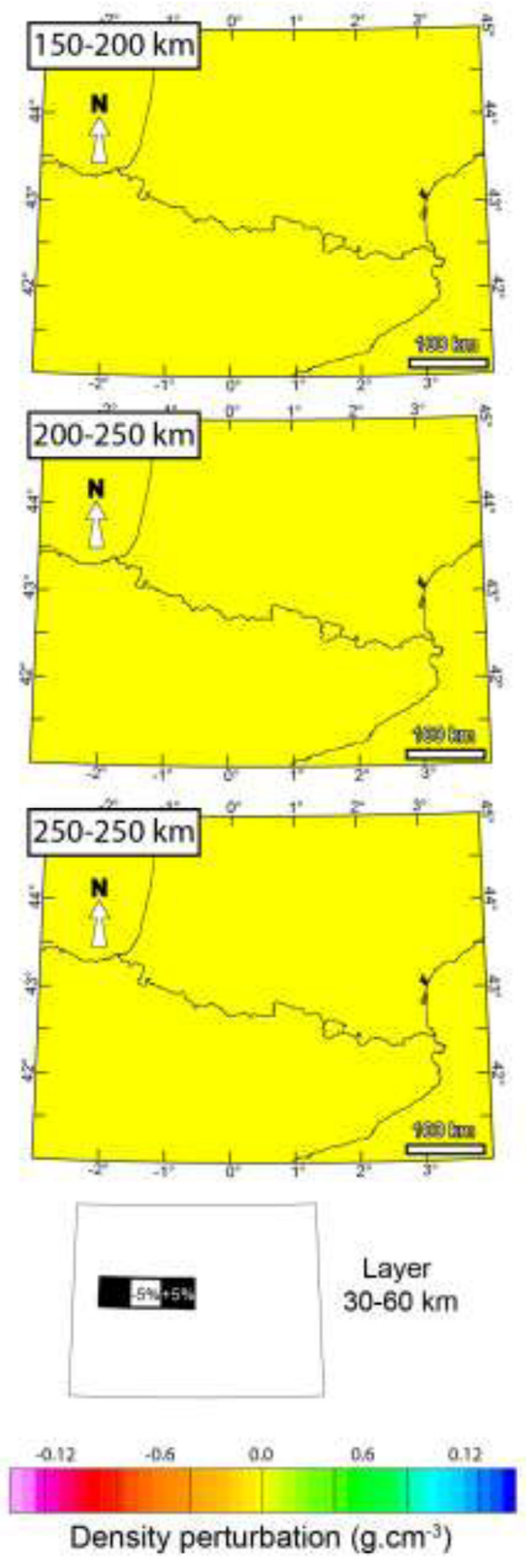

Figure 8. Output synthetic spikes (three anomalies) test for density model. The input density contrasts are \pm 0.5 per cent of the initial density model (Table 1 ) and are located in layers $30-60 \mathrm{~km}$. 

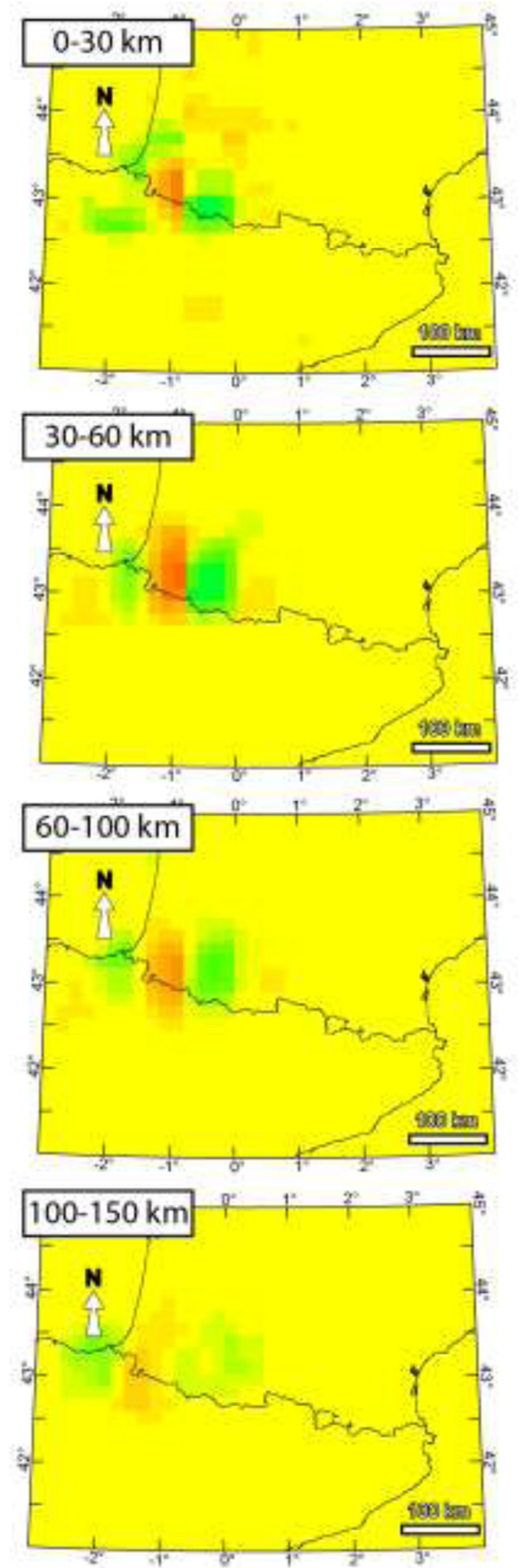
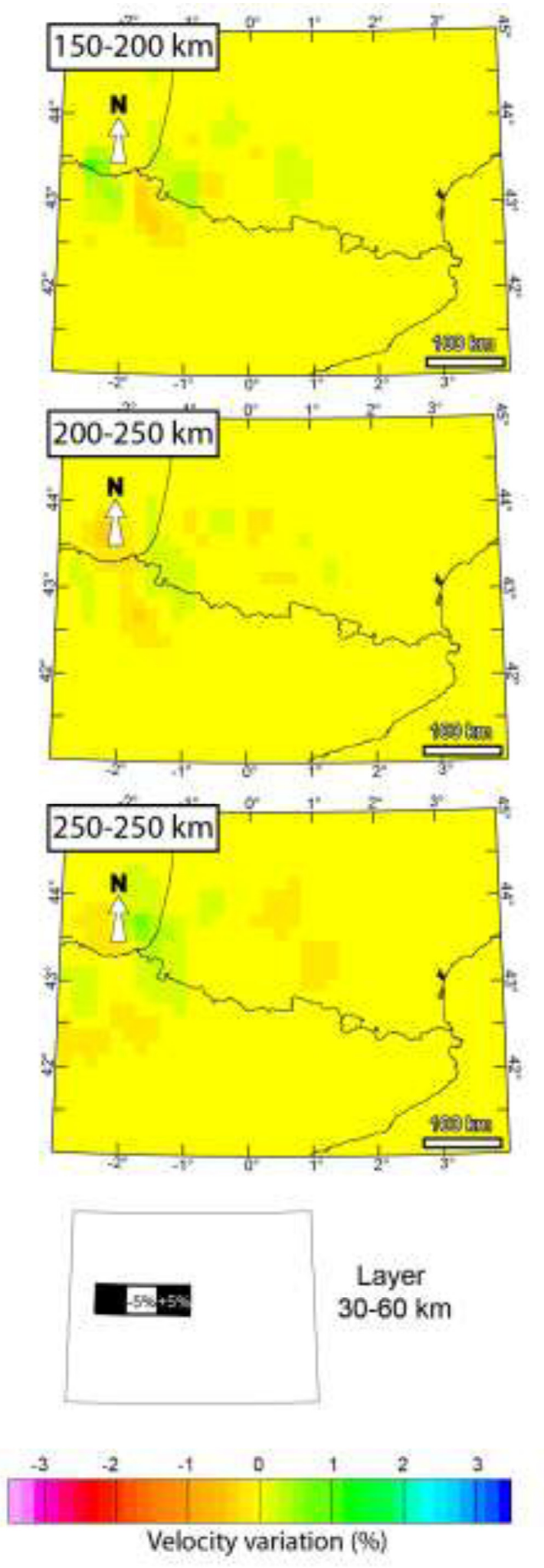

Figure 9. Output synthetic spikes (three anomalies) test for velocity model. The input velocity contrasts are \pm 0.5 per cent of the initial velocity model (Table 1 ) and are located in layer 30-60 km. 


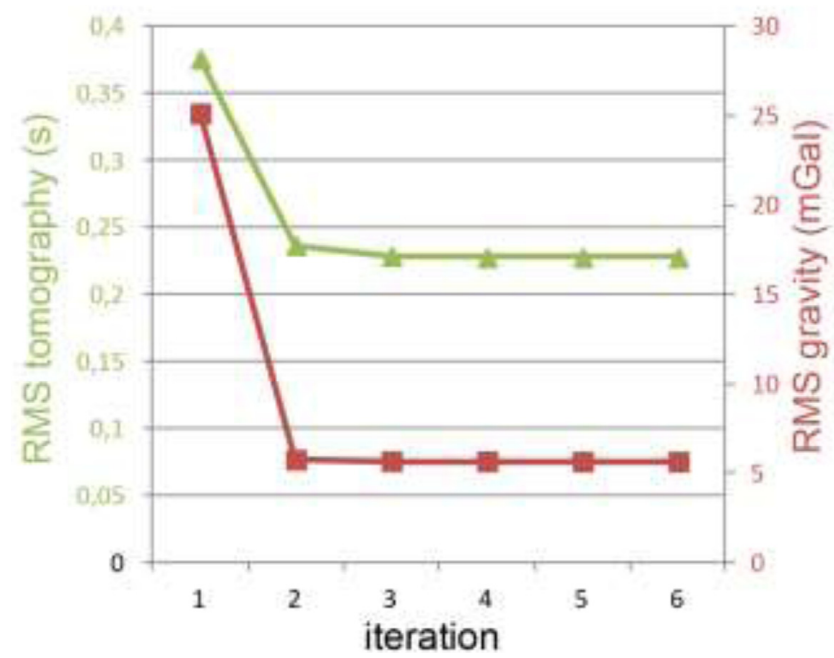

Figure 10. RMS evolution for delay times (green) and gravity anomalies (red) through the five iterations. Iteration 6 only corresponds to the final calculation of the anomalies, and does not invert the data.

\section{RESULTS AND TECTONIC DISCUSSION}

Our joint inversion model is now compared to recent tomographic models to discuss its implications in terms of geodynamical evolution of the area. Previous tomographic studies of the Pyrenees (i.e. Souriau et al. 2008; Chevrot et al. 2014) relied on crustal corrections, considering that the strong Moho topography may generate strong artefacts in the upper mantle (Souriau et al. 2008). Souriau et al. (2008) used the station altitudes, the thickness and $P$-velocity of the sedimentary layers to calculate their crustal correction. Chevrot et al. (2014) calculated a crustal correction from a crust model derived from a compilation of different regional models (i.e. Ziegler \& Dèzes 2006; Diaz \& Gallart 2009; Gómez-Ortiz et al. 2011) as well as receiver function studies and attributed a constant $P$-velocity for the entire crust. Changes in the velocity model can be consequently large above $125 \mathrm{~km}$ depth, but smaller below (see Souriau et al. 2008; Chevrot et al. 2014). Previous crustal corrections performed in the Pyrenees correspond to a simple reduction of the crust effect without lateral or vertical $P$-velocity variations (see CRUST 1.0; Laske et al. 2013). Neglecting effects of metamorphism, tectonic or pressure increase with depth within the crust may introduce inaccurate and erroneous correction values in velocity. Moreover, the gravity signal used in our inversion reflects mass distribution within the crust and the upper mantle, and contains all of these above-mentioned terms. Consequently, in order to preserve consistency between our gravity and delay time data set and to limit the introduction of spurious signal related to crustal effect reduction, crustal correction was not applied.

The resulting velocity model is characterized by a wide orogenparallel low-velocity anomaly from the surface $(\mathrm{ca}$. -2.5 in layer 0-30 km) down to $100 \mathrm{~km}$ depth centred beneath the Pyrenees (Fig. 12). This anomaly broadly corresponds to a deeper Moho and a crust/lithosphere thickening in southern Pyrenees caused by plate collision and underthrusting of the Iberia plate below the Eurasian plate (see Fig. 1b). The crustal part of our velocity model in the Pyrenees seems thus primarily dominated by crustal thickening and smearing effect through the entire first two layers. Consequently, a low-velocity anomaly in the uppermost crustal layer of our velocity model (i.e. 0-30 km) appears in the core of the Pyrenees where a high-velocity zone is expected due to the presence of metamorphic

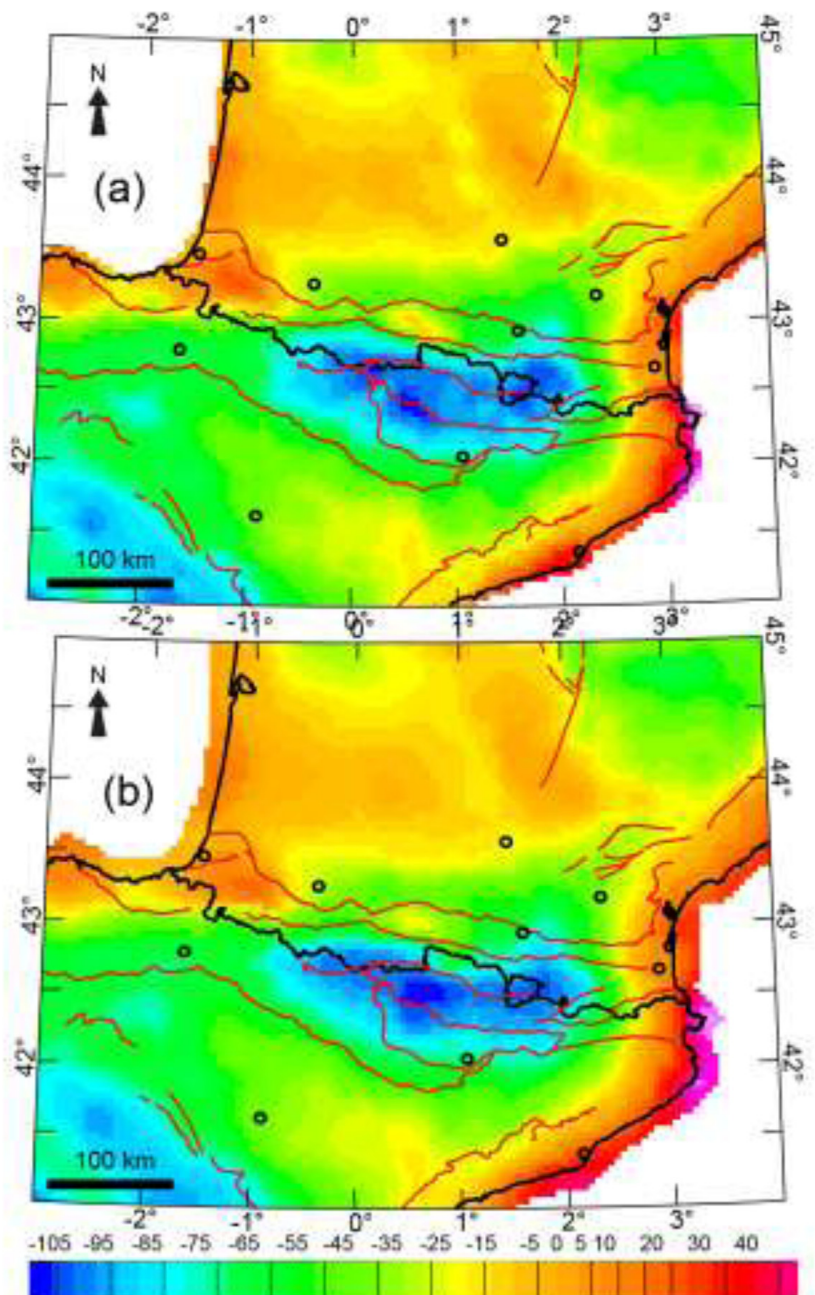

Complete Bouguer anomaly upward continued to $3 \mathrm{~km}$ (mGal)

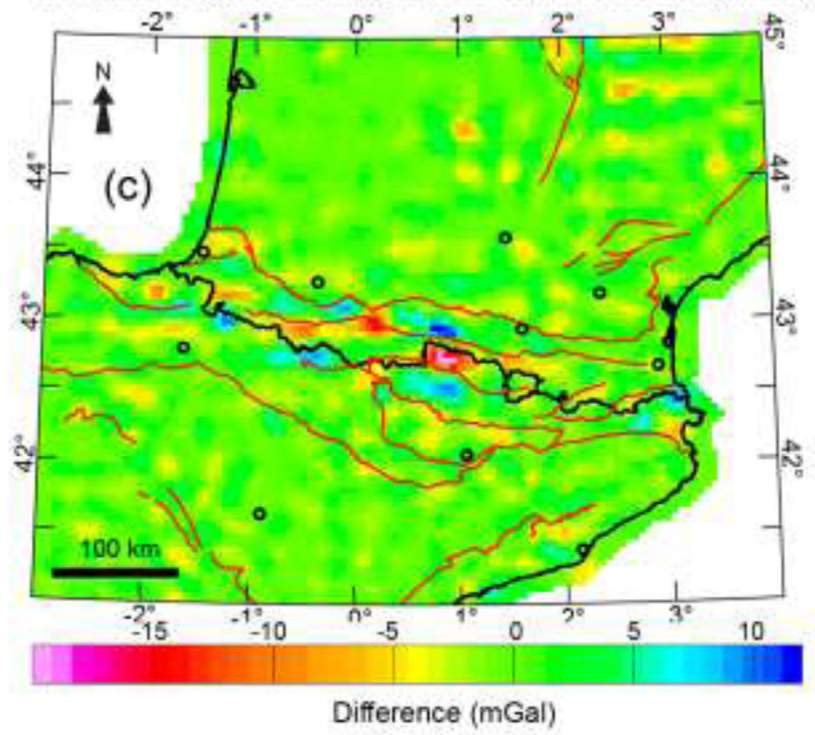

Figure 11. (a) Map of the observed complete Bouguer gravity anomaly used for joint inversion. (b) Map of the complete Bouguer gravity anomaly calculated from our resulting density model. (c) Map of the difference between the measured (a) and calculated (b) complete Bouguer anomalies. 

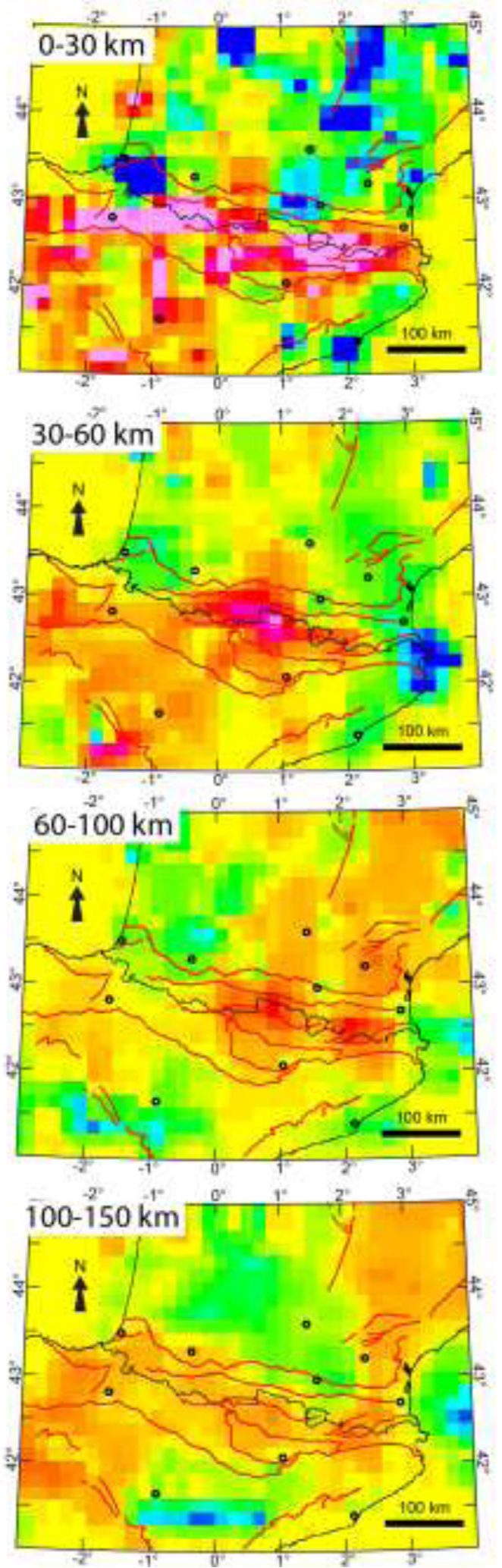
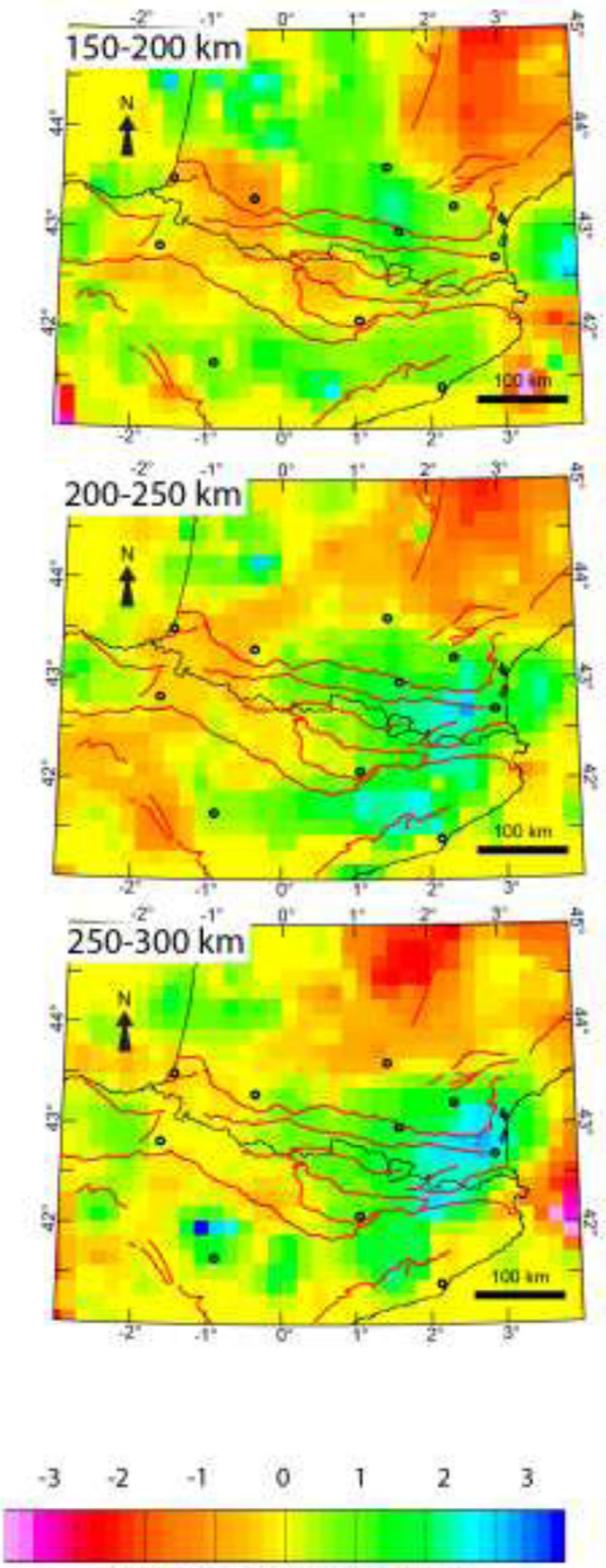

Velocity perturbation (\%)

Figure 12. Final velocity model from our joint inversion. The main tectonic faults are reported for each depth slice.

Variscan rocks with higher velocity than surrounding units (Fig. 12). The Labourd anomaly is associated with a high-velocity anomaly, which is well defined in the layer $0-30 \mathrm{~km}$, and progressively attenuated in the layers $30-60$ and $60-100 \mathrm{~km}$ (Fig. 12). Such smearing effect in the lithosphere part of our velocity model is confirmed by the checkerboard test (Figs 7 and 9). We get more detailed information of the structure on the Pyrenean lithosphere from our density model, which is more sensitive to shallower sources (Fig. 4). We 
thus preferentially define the lithospheric structure of the Pyrenees from the density model (Fig. 13). Because of the lower resolution of density model below $60 \mathrm{~km}$ depth, we will discuss the asthenospheric structure of the area from the analysis of the velocity model (Fig. 12).

The uppermost part of our crustal density model $(0-30 \mathrm{~km}$; Fig. 13) is characterized by an elongated E-Contract Rep.Wtrending negative density anomaly $\left(c a .-0.1 \mathrm{~g} \mathrm{~cm}^{-3}\right)$, also associated with a low-velocity zone $(c a .-2$ per cent $)$ in Fig. 12, that corresponds to the Pyrenees range and its deep Moho. Consequently, the $0-30 \mathrm{~km}$ density layer of our model is strongly affected by the Pyrenean crust thickness. The abrupt Moho jump evidenced in the receiver function data (Fig. 1b) is clearly identifiable in our model through the sharp northern border of this Pyrenees low density/velocity anomaly (layer 0-30 km; Figs 12 and 13). The layer 0-30 km also displays two positive density anomalies $(c a .+0.1 \mathrm{~g}$ $\mathrm{cm}^{-3}$; Fig. 13) in the northwestern part of the Pyrenees, that correspond to the Labourd and Saint-Gaudens gravity anomalies (respectively labelled L and SG in Figs $2 b$ and $c$ and 13). The Labourd and Saint-Gaudens positive gravity anomalies are attributed to the upward emplacement of denser mantle material between the Eurasian and Iberia crust during plate collision. Note that the Saint-Gaudens density anomaly is limited in our model to the upper most crustal layer only (Fig. 13). The Variscan units in the Pyrenees (dense rocks mainly of the Axial Zone; see Fig. 1a) are not visible in our $0-30 \mathrm{~km}$ density layer where the dominant density response comes from crustal thickness. The Aquitanian and Ebro basins are respectively associated with a density anomaly of $c a .0$ and $0.02 \mathrm{~g}$ $\mathrm{cm}^{-3}$.

The $30-60 \mathrm{~km}$ density layer is dominated by a large negative density zone (from $c a$. -0.05 to $-0.15 \mathrm{~g} \mathrm{~cm}^{-3}$; Fig. 13) suggesting the presence of low density material beneath $30 \mathrm{~km}$ depth. This regional low density anomaly can be explained by higher crustal thickness (up to $50 \mathrm{~km}$ depth; Fig. 1b) beneath the Pyrenees and Spain that implies less dense material in the range of layer 2 dominated by mantle material. Even if receiver functions imaged thicker crust north of Andorra (ca. 35-40 km depth; Fig. 1b), our negative density anomaly exceeds these limits particularly in the northwestern part of the Pyrenees (see Chevrot et al. 2014; Mancilla et al. 2015 and Fig. 1b). Macquet et al. (2014) imaged the presence of a low-velocity Iberian crust underthrust beneath the Eurasian crust in the central Pyrenees. Northwest of the Pyrenees, Wang et al. (2016) imaged subducted Iberian crust at $c a$. $50 \mathrm{~km}$ depth beneath Eurasian crust and mantle material (which caused the Labourd anomaly). Following Macquet et al. (2014) and Wang et al. (2016), we interpret our negative density response in the northwestern and northern part of the Pyrenees (layer 30-60 km) by the presence of deep buried subducted Iberian crust and in the north-northeastern part of the Pyrenees (Foix area in Fig. 1b) by a thicker Eurasian crust of $c a$. $40 \mathrm{~km}$. In their profile, Wang et al. (2016) did not continue the subducted Iberian crust north of the NPTZ, although the negative anomaly in our model continues $c a .40 \mathrm{~km}$ northwards.

This negative anomaly encompasses two pronounced positive density features also identifiable in the underlying density layer 60-100 km (labelled L and C, Fig. 13). The westernmost positive density anomaly $\left(+2 \mathrm{~g} \mathrm{~cm}^{-3}\right.$; Fig. 13$)$ coincides with the Labourd gravity anomaly and is associated with a high-velocity zone. The central positive density anomaly $\left(+1 \mathrm{~g} \mathrm{~cm}^{-3}\right.$; labelled C in Fig. 13) is located east of Andorra, beneath the western part of the Axial Zone and is conversely associated with a low-velocity zone (Figs 12 and 13). Souriau et al. (2008) state that the transformation of lower crust material into eclogite at $\sim 50 \mathrm{~km}$ during continental subduction is difficult to detect from seismology because the velocity contrast between eclogite and mantle rock is very weak (e.g. Press 1966). In the Himalaya, Hetényi et al. (2007) show that the transformation of lower crust material into eclogite in the case of continental subduction weakened the velocity contrast within the mantle (Press 1966; Souriau et al. 2008), but is in contrast still present in the gravity signal and can therefore be deduced from gravity. Consequently (i) the absence of a high density anomaly in our model between 30-60 km (except the Labourd and the central density anomalies, see above) and 60-100 km along the northern part of the Pyrenees (Fig. 13) seems to exclude a broad eclogitization of the subducted Iberian lower crust in the northern part of the Pyrenees; and (ii) the central density anomaly imaged in our model broadly corresponds to the deeper part of the Pyrenean lower crust (west of Andorra; Fig. 1b). The nature of this anomaly is not clearly established but may materialize the local eclogitization of the deep root of the Pyrenees. The central density anomaly is not visible on the velocity model and presents similar characteristic with the eclogitized crust described by Hetényi et al. (2007) in the Himalaya. The presence of eclogites in layer 2 is likely to contribute to the reduced correlation between density and velocity reported at this depth (Table 1). Eclogites display significantly higher densities than olivine-dominated upper-mantle rocks, while their respective seismic velocities largely overlaps, opposite to the Birch's law trend (Kern 1993; Christensen 1996, Afonso et al. 2013).

The density 30-60 km layer displays an east-west along-strike segmentation of the Pyrenees range characterized by successive positive and negative anomalies (Fig. 13). A segmented pattern is also present in the velocity model down to $60 \mathrm{~km}$ depth: the western Pyrenees are associated with positive velocity anomaly ( 0 to 1 per cent; Fig. 12) whereas the eastern Pyrenees are associated with a lowvelocity zone ( -1 to -2 per cent; Fig. 12). Chevrot et al. (2014) also imaged an east-west succession of low- and high-velocity anomalies in the Pyrenees at $c a .50 \mathrm{~km}$ depth, which are similar with the density anomalies at $30-60 \mathrm{~km}$ depth. The along-strike segmentation and role of reactivated structures during Alpine compression and Pyrenees formation was discussed by Chevrot et al. (2014). They attempt to connect the surface expression of both the Sillon Houiller fault, a major N20 Hercynian fault (Burg et al. 1990), and the Pamplona fault, an $\mathrm{N} 20^{\circ}$-trending transverse fault (Larrasoaña et al. 2003 and references therein), to their regional tomographic model. They proposed that these two faults were reactivated during the Cretaceous rifting of the Aquitaine and Iberian margins and during the Cenozoic Alpine convergence, and have a strong imprint on lithospheric structures in the Pyrenees. However, in our density and velocity models, neither the Sillon Houiller nor the Pamplona fault are clearly associated with anomalies in the lithospheric layers in the Pyrenees (Figs 12 and 13), as expected for major faults or shear zones (e.g. Dufréchou \& Harris 2013; Dufréchou et al. 2014). In our model, the Sillon Houiller is located at the western border of a negative density (Fig. 13) and velocity (down to $100 \mathrm{~km}$ depth; Fig. 12) anomaly beneath the Massif Central (corresponding to a thermal anomaly, Chevrot et al. 2014), but cannot be traced south of the latitude $44^{\circ} \mathrm{N}$. Although our model does not exclude the contribution of the Sillon Houiller and Pamplona fault in the Pyrenees tectonic evolution, it did not support it either.

Furthermore, the Pyrenees are also characterized by an east-west along-strike partitioning of the earthquake's location (Fig. 14a); most of them are located in the depth range 5-15 km with a normal mechanism (Chevrot et al. 2011). In the western-central part of the Pyrenees, earthquakes are concentrated close to the North Pyrenean Fault (see Rigo et al. 2005; Souriau et al. 2014). Their concentration 

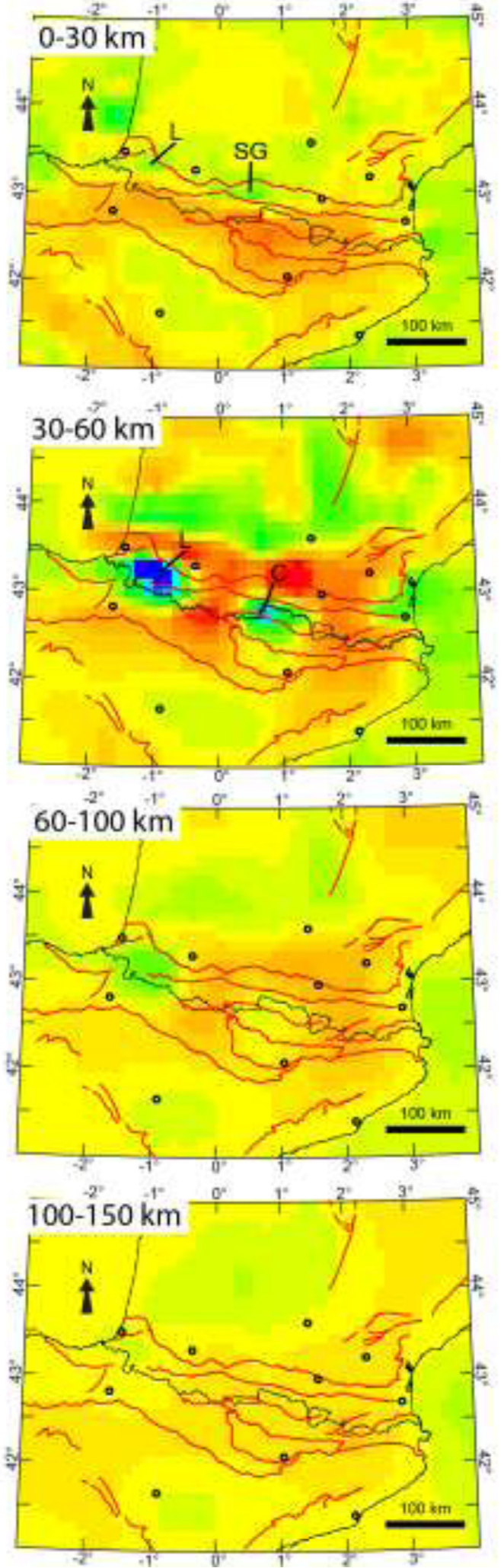
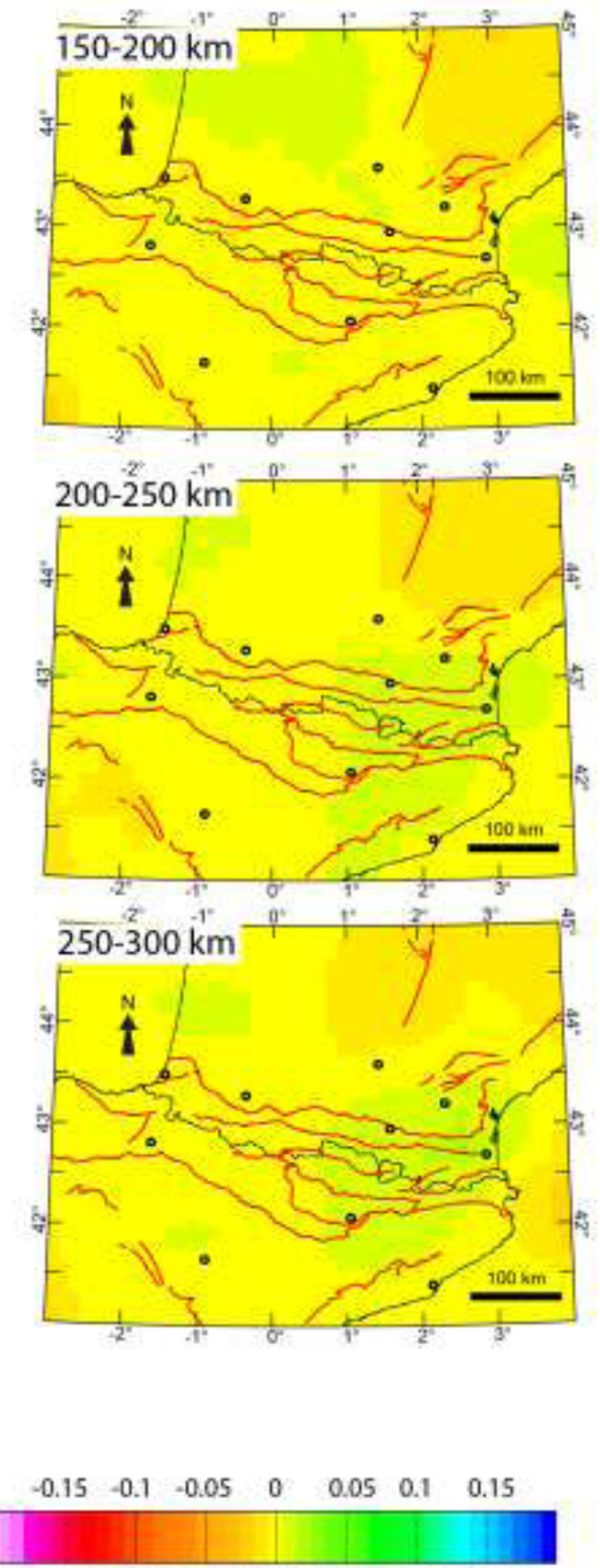

Density perturbation $\left(\mathrm{g} \cdot \mathrm{cm}^{-3}\right)$

Figure 13. Final density model from our joint inversion. The main tectonic faults are reported for each depth slice. C: central anomaly; L: Labourd anomaly; SG: Saint-Gaudens anomaly.

is a possible consequence of the subsidence of dense exhumed mantle bodies, associated with the Labourd and Saint-Gaudens gravity and density anomalies (Figs 2a and 14a; Souriau et al. 2014). Note that seismic activities in the Lacq area in France and Pamplona area in Spain are attributed to anthropogenic activity (Fig. 14a). In the 


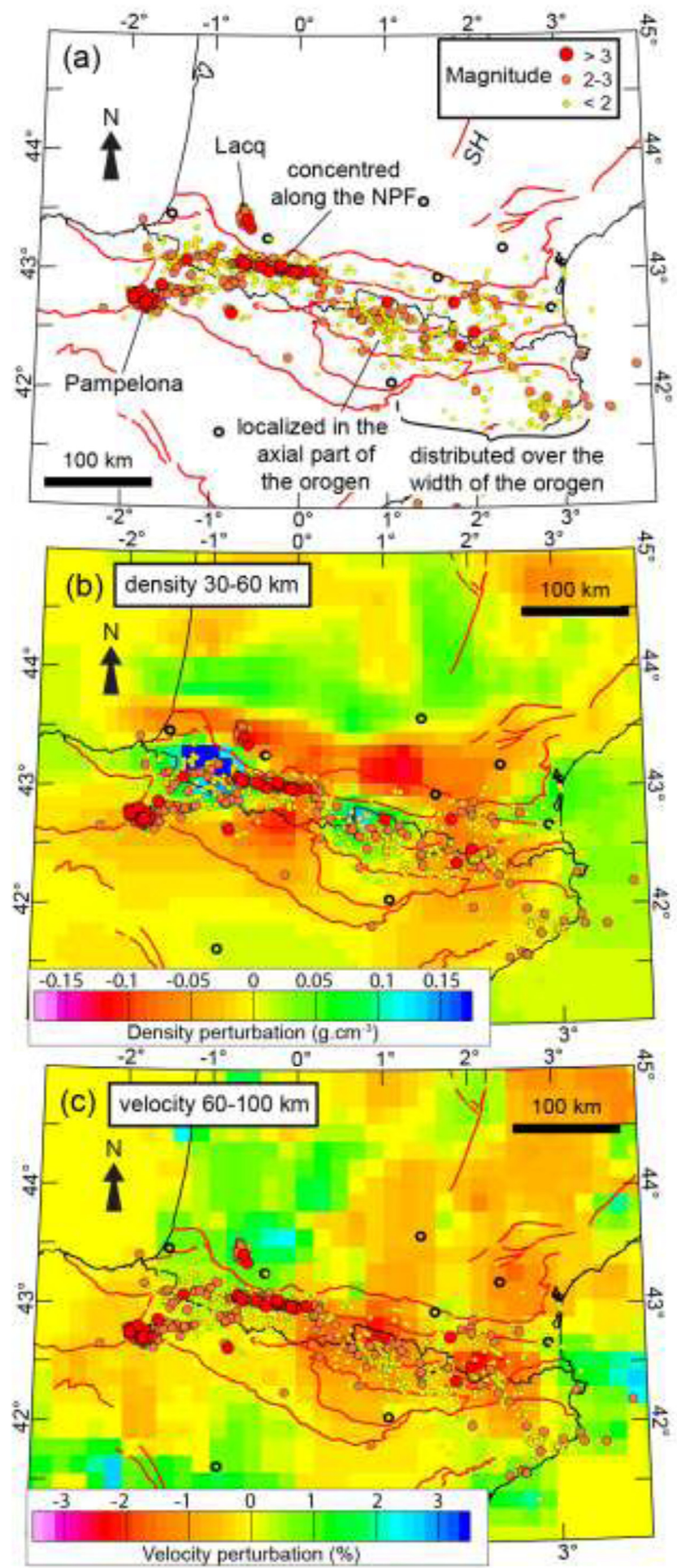

Figure 14. (a) Seismicity in the Pyrenees (January-December 2013; depth range $5-15 \mathrm{~km}$ ) with superimposed main faults displaying the three seismic zones (Rigo et al. 2005; Chevrot et al. 2011). (b) Seismicity in the Pyrenees (January-December 2013) with superimposed main faults and the density layer 30-60 km (Fig. 12). (c) Seismicity in the Pyrenees (January-December 2013) with superimposed main faults and the velocity layer $60-100 \mathrm{~km}$ (Fig. 13). Source: Réseau de Surveillance Sismique des Pyrénées (RSSP; http://rssp.irap.omp.eu/). SH: Sillon Houiller. central part of the Pyrenees (west of Andorra; Fig. 14a), the seismicity is mostly located in the axial part of the orogen. In the eastern part, the seismicity is distributed over the entire width of the orogen and extends further beneath the Mediterranean domain (Fig. 14a). Earthquakes in the central part of the Pyrenees are localized just straight up the central density anomaly (Fig. 14b). Furthermore, the western NPF seismic zone of the Pyrenees is located above a high-velocity zone (30-60 km depth), whereas the seismic zones in the axial and eastern part of the Pyrenees are located above a low-velocity zone (Fig. 14c). This E-W segmentation of the seismicity along the Pyrenees range broadly coincides with distinct lithospheric density (layer 30-60; Fig. 14b) and velocity (layer 60$100 \mathrm{~km}$; Fig. 14c) domains of our model. It suggests a possible relation between the Pyrenean deep structure and the seismicity in the Pyrenees. The concomitance of crustal seismicity and the central density anomaly can reflect the subsidence and/or delamination of an eclogitized Pyrenean deep root, similarly to the Betic range (Mancilla et al. 2013). The delamination of the range affects the seismicity atop by inducing fundamental changes in deformation patterns within the collision orogen. Further detailed analyses and more local data are however required to fully confirm the possible contribution of the Pyrenean deep structure in the present seismicity.

The low-velocity zone associated withContract Rep. the Pyrenees and present in the uppermost layers disappears below $150 \mathrm{~km}$. The Pyrenean asthenosphere (from $150 \mathrm{~km}$ depth) is marked by a strong E-W contrast between a western low-velocity mantle ( $c a$. -1.6 per cent; Fig. 12) and an eastern high-velocity anomaly (ca. +2 per cent; Fig. 12), as previously observed (Souriau et al. 2008; Chevrot et al. 2014). At a broader scale, consistent tomographic images were obtained by Piromallo \& Morelli (2003) beneath the Pyrenees at $300 \mathrm{~km}$ depth. In our model, the low-velocity anomaly ( $c a$. -1 per cent) in the western part of the Pyrenees encompasses the western part of the Ebro basin and starts to vanish below $250 \mathrm{~km}$. The wide slightly high-velocity anomaly encircles the Aquitanian basin, the eastern part of the Pyrenees and the eastern part of the Ebro basin. Finally, the southwest part of the Massif Central is also marked by a low-velocity anomaly ( $c a$. -1 per cent), which reaches its maximum amplitude at $250 \mathrm{~km}$ and seems to correspond to a deep rooted anomaly, even if considering smearing effect. The signature of the Massif Central is coherent with the study of Piromallo \& Morelli (2003) and Zhu et al. (2012) at $150 \mathrm{~km}$ depth. The asthenospheric part of our velocity model provides a similar distribution of velocity anomalies from 100 to $250 \mathrm{~km}$ (Fig. 12), probably partly caused by smearing effect suggested by our synthetic test (Figs 7 and 9). Similarly to previous results of regional tomography (Souriau et al. 2008; Chevrot et al. 2014), the absence of a high-velocity anomaly in the upper mantle and transition zone (i.e. 125 to $225 \mathrm{~km}$; Fig. 12) seems to exclude the presence of a detached oceanic lithosphere beneath the European plate and seems to confirm previous interpretation of regional tomography.

\section{CONCLUSIONS}

Imaging the deep architecture of continental orogens is fundamental to understanding the geodynamic of convergent plate boundaries. In this study, we present a new model of the lithosphere and asthenosphere structure down to $300 \mathrm{~km}$ beneath the Pyrenees, conciliating abundant gravity and recent teleseismic data. Joint inversion was performed without crustal correction in order to preserve the consistency between the gravity and traveltime data sets and to avoid biases from incomplete crustal reductions. The gravity signal used 
in our model mainly reflects the mass distribution within the lithosphere and was thus preferentially used down to $100 \mathrm{~km}$ to discuss the lithospheric structure of the Pyrenees, whereas the asthenospheric structure from 100 to $300 \mathrm{~km}$ was preferentially discussed from our velocity model. The first three layers of our velocity model are mainly affected by crustal thickness variations.

The uppermost part of our model is characterized by an elongated E-W-trending negative density and low-velocity anomalies that correspond to the Pyrenees range and its deep Moho. The abrupt Moho jump in the Pyrenees is clearly identifiable in our model through the sharp northern border of this Pyrenees low density/velocity anomaly. The well-known Labourd and Saint-Gaudens gravity anomalies are clearly visible in our density model. A large negative density zone between 30 and $60 \mathrm{~km}$ is explained by higher crustal thickness beneath the Pyrenees and Spain, and by the combination of low density underthrust Iberian crust beneath the Eurasian crust in the northwestern and north-central part, and a thicker Eurasian crust of $c a .40 \mathrm{~km}$ in the centre/western part.

The absence of a high density anomaly north of the Pyrenees between $30-60$ and $60-100 \mathrm{~km}$ suggests that if eclogitization of the Iberian underthrust crust can't be deduced at the scale of the entire Pyrenean range, it can be present more locally. Indeed, the central positive density anomaly (located beneath the western part of the Axial Zone, west of Andorra) is associated with the deeper part of the Pyrenean crust, presents similar characteristics with the eclogitized crust in the Himalaya, and may materialize the local eclogitization of the deep Pyrenean root.

The Pyrenean lithosphere displays an east-west segmentation of the range that could be related to the different seismicity between the western part (concentrated close to the North Pyrenean Fault) and eastern part (located in the axial part and distributed over the entire width of the orogen in the easternmost part) of the Pyrenees. It suggests a possible relation between the Pyrenean deep structures and the seismicity in the Pyrenees. The concentration of earthquakes localized just straight up the central density anomaly can reflect the subsidence and/or delamination of an eclogitized Pyrenean deep root.

The asthenospheric part of our velocity model provides a comparable distribution of velocity anomalies to those imaged in previous studies. The absence of a high-velocity anomaly in the upper mantle and transition zone (i.e. 125-225 km depth) seems to exclude the presence of a detached oceanic lithosphere beneath the European plate and seems to confirm the results of previous regional tomography in this region.

\section{ACKNOWLEDGEMENTS}

The authors acknowledge the Centre National d'Etudes Spatiales (CNES) and its TOSCA program for the financial support and the post-doctoral position of Grégory Dufréchou, and the French Research Agency ANR blanc program (PYROPE experiment, ANR09-BLAN-0229). We are grateful to the Bureau Gravimétrique International for providing gravity data and gravity field support for measurements in the eastern part of the Pyrenees. The Institut National des Sciences de l'Univers (INSU) is also acknowledged for providing the gravimeters from GMOB. Anne Briais, Joseph Martinod, Stéphane Mazzotti, Alexandra Robert and Alizia Tarayoun are gratefully thanked for their help during gravity measurements. We also acknowledge Matthieu Sylvander from the Réseau de Surveillance Sismique des Pyrénées (RSSP) who provided the seismicity data. We gratefully thank three anonymous reviewers for their constructive reviews that helped to improve the manuscript.

\section{REFERENCES}

Abers, G.A., 1994. Three-dimensional inversion of regional $\mathrm{P}$ and $\mathrm{S}$ arrival times in the East Aleutians and sources of subduction zone gravity highs, J. geophys. Res., 99, 4395-4412.

Afonso, J.C., Fullea, J., Griffin, W.L., Yang, Y., Jones, A.G., Connolly, J.A.D. \& O'Reilly, S.Y., 2013. 3-D multiobservable probabilistic inversion for the compositional and thermal structure of the lithosphere and upper mantle. I: a priori petrological information and geophysical observables, J. geophys. Res., 118, 2586-2617.

Barnett-Moore, N., Müller, D.R., Williams, S., Skogseid, J. \& Seton, M., 2016. A reconstruction of the North Atlantic since the earliest Jurassic, Basin Research, doi:10.1111/bre.12214.

Basuyau, C. \& Tiberi, C., 2011. Imaging lithospheric interfaces and 3D structures using receiver functions, gravity, and tomography in a common inversion scheme, Comput. Geosci., 37, 1381-1390.

Basuyau, C., Diament, M., Tiberi, C., Hetényi, G., Vergne, J. \& Peyrefitte, A., 2013. Joint inversion of teleseismic and GOCE gravity data: application to the Himalayas, Geophys. J. Int., 193, 149-160.

Birch, F., 1961. The velocity of compressional waves in rocks to 10 kilobars: 2, J. geophys. Res., 66, 2199-2224.

Blakely, R.C, 1995. Potential Theory in Gravity and Magnetic Applications, p. 441. Cambridge Univ. Press.

Bonnin, M., Chevrot, S., Gaudot, I. \& Haugmard, M., 2017. Upper-mantle deformation beneath the Pyrenean domain inferred from SKS splitting in northern Spain and southern France, Geophys. J. Int., 210, 898-910.

Briggs, I., 1974. Machine contouring using minimum curvature, Geophysics, 39, 39-48.

Burg, J.P., Brun, J.P. \& Van Den Driessche, J., 1990. Le sillon houiller du massif central français: faille de transfert pendant l'amincissement crustal de la chaîne varisque? C. R. Acad. Sci., 311, 147-152.

Burg, J.P., Van Den Driessche, J. \& Brun, J.P., 1994. Syn to post-thickening extension: in the Variscan Belt of Western Europe: modes and structural consequences, Géol. France, 3, 33-51.

Campanyà, J., Ledo, J., Queralt, P., Marcuello, A., Liesa, M. \& Muñoz, J.A., 2012. New geoelectrical characterisation of a continental collision zone in the West-Central Pyrenees: constraints from long period and broadband magnetotellurics, Earth planet. Sci. Lett., 333-334, 112-121.

Carballo, A., Fernandez, M., Torne, M., Jiménez-Munt, I. \& Villaseñor, A., 2014. Thermal and petrophysical characterization of the lithospheric mantle along the northeastern Iberia geo-transect, Gondwana Res., 27, 1430-1445.

Casas, A., Kearey, P., Rivero, L. \& Adam, C.R., 1997. Gravity anomaly map of the Pyrenean region and a comparison of the deep geological structure of the western and eastern Pyrenees, Earth planet. Sci. Lett., 150, 65-78.

Chevrot, S., Sylvander, M. \& Delouis, B., 2011. A preliminary catalog of moment tensors for the Pyrenees, Tectonophysics, 510, 239-251.

Chevrot, S. et al., 2014. High resolution imaging of the Pyrenees and Massif Central from the data of the PYROPE and IBERARRAY portable array deployments, J. geophys. Res., 119, 6399-6240.

Chevrot, S., Sylvander, M., Diaz, J., Ruiz, M. \& Paul, A., Pyrope Working Group, 2015. The Pyrenean architecture as revealed by teleseismic $P$-to$S$ converted waves recorded along two dense transects, Geophys. J. Int., 200, 1096-1107

Choukroune, P. \& Mattauer, M., 1978. Tectonique des plaques et Pyrénées: Sur le fonctionnement de la faille transformante nord-pyrénéenne: comparaisons avec des modèles actuels, Bull. Soc. Géol. France, 7, 689-700.

Choukroune, P., 1989. The ECORS Pyrenean deep seismic profile reflection data and the overall structure of an orogenic belt, Tectonics, 8, 23-39.

Choukroune, P., Roure, F. \& Pinet, B., 1990. Main results of the ECORS Pyrenees profile, Tectonophysics, 173, 411-423.

Christensen, N., 1996, Poisson's ratio and crustal seismology, J. geophys. Res., 101, 3139-3156. 
Corchete, V., Badal, J., Serón, F.J. \& Soria, A., 1995. Tomographic images of the Iberian subcrustal lithosphère and asthenosphere, J. geophys. Res., 100, 24133-24146.

Corpel, J. \& Casas, A., 1996. Gravimétrie, in Structures Profondes-Apport de la Géophysique à Terre, in Synthèse Géologique et Géophysique des Pyrénées, pp. 38-41, eds Barnolas, A. \& Chiron, J.C., BRGM.

Daignières, M., Gallart, J. \& Banda, E., 1981. Lateral variation of the crust in the North Pyrenean zone, Ann. Geophys., 37, 435-456.

Daignières, M., Gallart, J., Banda, E. \& Hirn, A., 1982. Implications of the seismic structure for the orogenic evolution of the Pyrenees range, Earth planet. Sci. Lett., 57, 88-110.

Daignières, M., Séguret, M. \& Specht, M., \& ECORS Team, 1994. The Arzacq-Western Pyrenees ECORS deep seismic profile, in Hydrocarbon and Petroleum Geology of France. Special Publication of the European Association of Petroleum Geoscientists 4, p. 199-208, ed. Mascle, A., Springer.

Díaz, J. \& Gallart, J., 2009. Crustal structure beneath the Iberian Peninsula and surrounding waters: A new compilation of deep seismic sounding results, Phys. Earth planet. Inter., 173, 181-190.

Dufréchou, G. \& Harris, L.B., 2013. Tectonic models for the origin of regional transverse structures in the Grenville Province of SW Quebec interpreted from regional gravity, J. Geodyn., 64, 15-39.

Dufréchou, G., Harris, L.B. \& Corriveau, L., 2014. Tectonic reactivation of transverse basement structures in the Grenville orogen of SW Quebec, Canada: insights from gravity and aeromagnetic data, Precambrian Res., 241, 61-84.

ECORS Pyrenees team, 1988. The ECORS deep reflection seismic survey across the Pyrenees, Nature, 331, 508-511.

Forsberg, R. \& Tscherning, C.C., 2008. An overview manual for the GRAVSOFT geodetic gravity field modelling programs, Contract Rep., JUPEM.

Foulger, G.R. et al., 2013. Caveats on tomographic images, Terra Nova, 25, 259-281.

Gallart, J., Daignières, M., Banda, E., Surinach, E. \& Hirn, A., 1980. The Eastern Pyrenean domain: lateral variations at crust-mantle level, Ann. Geophys., 36, 457-480.

Gallart, J., Banda, E. \& Daignières, M., 1981. Crustal structure of the Paleozoic axial zone of the Pyrenees and transition to the north Pyrenean zone, Ann. Geophys., 37, 457-480.

Gómez-Ortiz, D., Agarwal, B.N.P., Tejero, R. \& Ruiz, J., 2011. Crustal structure from gravity signatures in the Iberian Peninsula, Geol. Soc. Am. Bull., 123, 1247-1257.

Grandjean, G., 1994. Etude des structures crustales dans une portion de chaîne et leur relation avec les bassins sédimentaires. Application aux Pyrénées occidentales, Bull. Cent. Rech. Explor. Prod. Elf-Aquitaine Prod., 18, 391-419.

Gunnell, Y., Zeyen, H. \& Calvet, M., 2008. Geophysical evidence of a missing lithospheric root beneath the Eastern Pyrenees: consequences for post-orogenic uplift and associated geomorphic signatures, Earth planet. Sci. Lett., 276, 302-313.

Hansen, P., 2001. The L-curve and its use in the numerical treatment of inverse problems, in computational inverse problems in electrocardiology, in Advances in Computational Bioengineering, Vol. 5, pp. 119 142, ed. Johnston, P., WIT Press.

Hetényi, G., Cattin, R., Brunet, F., Bollinger, L., Vergne, J., Nábělek, J.L. \& Diament, M., 2007. Density distribution of the India plate beneath the Tibetan plateau: geophysical and petrological constraints on the kinetics of lower-crustal eclogitization, Earth planet. Sci. Lett., 264, 226-244.

Hirn, A., Daignières, M., Gallart, J. \& Vadell, M., 1980. Explosion seismic sounding of throws and dips in the continental Moho, Geophys. Res. Lett., 7, 263-266.

Jammes, S., Manatschal, G., Lavier, L. \& Masini, E., 2009. Tectonosedimentary evolution related to extreme crustal thinning ahead of a propagating ocean: example of the western Pyrenees, Tectonics, 28, TC4012, doi:10.1029/2008TC002406.

Kennett, B.L.N., Engdahl, E.R. \& Buland, R., 1995. Constraints on seismic velocities in the Earth from traveltimes, Geophys. J. Int., 122, 108-124.
Kern, H., 1993. Physical properties of crustal and upper mantle rocks with regards to lithosphere dynamics and high pressure mineralogy, Phys. Earth Planet. Inter., 79, 113-136.

Larrasoaña, J.C., Parés, J.M., Millán, H., del Valle, J. \& Pueyo, E.L., 2003. Paleomagnetic, structural, and stratigraphic constraints on transverse fault kinematics during basin inversion: the Pamplona fault (Pyrenees, north Spain), Tectonics, 22, 1071, doi:10.1029/2002TC001446.

Laske, G., Masters, G., Ma, Z. \& Pasyanos, M., 2013. Update on CRUST1.0 - A 1-degree Global Model of Earth's Crust, Geophys. Res. Abstracts 15, EGU2013-2658.

Le Pichon, X., Bonnin, J. \& Sibuet, J.-C., 1970. La faille nord-pyrénéenne: Faille transformante liée à l'ouverture du golfe de Gascogne, C. R. Acad. Sci., 271, 1941-1944.

Ledo, J., Ayala, C., Pous, J., Queralt, P., Marcuello, A. \& Muñoz, J.A., 2000. New geophysical constraints on the deep structure of the Pyrenees, Geophys. Res. Lett., 27, 1037-1040.

Macquet, M., Paul, A., Pedersen, H.A., Villaseñor, A., Chevrot, S., Sylvander, M. \& Wolyniec, D., Pyrope Working Group, 2014. Ambient noise tomography of the Pyrenees and the surrounding regions: inversion for a 3 -D Vs model in the presence of a very heterogeneous crust, Geophys. J. Int., 199, 402-415.

Mancilla, F.d.L. \& Diaz, J. 2015. High resolution Moho topography map beneath Iberia and Northern Morocco from receiver function analysis, Tectonophysics, 663, 203-211.

Mancilla, F.d.L., Stich, D., Berrocoso, M., Martín, R., Morales, J., Fernandez-Ros, A., Páez, R. \& Pérez-Peña, A., 2013. Delamination in the Betic Range: deep structure, seismicity, and GPS motion, Geology, 41, 307-310.

Mancilla, F.d.L. et al., 2015. Crustal thickness and images of the lithospheric discontinuities in the Gibraltar arc and surrounding areas, Geophys. J. Int., 203, 1804-1820.

Martin, R. et al., 2017. A high-order 3-D spectral-element method for the forward modelling and inversion of gravimetric data - application to the western Pyrenees, Geophys. J. Int., 209, 406-424.

Mattauer, M. \& Seguret, M., 1971. Les relations entre la chaîne des Pyrénées et le golfe de Gascogne, in Histoire structurale du Golfe de Gascogne, pp. 1-24, eds Debyser, J., Le Pichon, X. \& Montadert, L., Technip.

Matte, P., 1986. Tectonics and plate tectonics model for the Variscan belt of Europe, Tectonophysics, 126, 329-374.

Menke, W., 1984. The resolving power of cross-borehole tomography, Geophys. Res. Lett., 11, 105-108.

Mouthereau, F. et al., 2014. Placing limits to shortening evolution in the Pyrenees: Role of margin architecture and implications for the Iberia/Europe convergence, Tectonics, 33, 2283-2314.

Nolet, G., 1990. Partitioned waveform inversion and two-dimensional structure under the network of autonomously recording seismographs, J. geophys. Res., 95, 8499-8512.

Pedreira, D., Pulgar, J.A., Gallart, J. \& Torné, M., 2007. Three-dimensional gravity and magnetic modeling of crustal indentation and wedging in the western Pyrenees-Cantabrian mountains, J. geophys. Res., 112, B12405, doi:10.1029/2007JB005021.

Piromallo, C. \& Morelli, A., 2003. P wave tomography of the mantle under the Alpine-Mediterranean area, J. geophys. Res., 108, 2065, doi:10.1029/2002JB001757.

Pous, J., Ledo, J.J., Queralt, P. \& Muñoz, J.A., 1997. Constraints on the deep structure of the Pyrenees from new magnetotelluric data, Rev. Soc. Geol. España, 8, 395-400.

Press, F., 1966. Section 9: Seismic velocities, Geol. Soc. Am. Mem., 97, $195-218$.

Rigo, A., Souriau, A., Dubos, N., Sylvander, M. \& Ponsolles, C., 2005. Analysis of the seismicity in the central part of the Pyrenees (France) and tectonic implications, J. Seismol., 9, 211-222.

Roca, E. et al., 2004. TRANSMED-Transect III: Aquitaine Basin, Pyrenees, Ebro Basin, Catalan Range, Valencia Trough, Balearic Block, Algerian Basin, Kabylies, Atlas, Saharian Platform, in The TRANSMED Atlas: the Mediterranean Region from Crust to Mantle, pp. 97-102, eds Cavazza, W., Roure, F., Spakman, W., Stampfli, G.M. \& Ziegler, P.A., Springer-Verlag. 
Roure, F. et al., 1989. ECORS deep seismic data and balanced cross sections: Geometric constraints on the evolution of the Pyrenees, Tectonics, 8, 4150 .

Séguret, M. \& Daignieres, M., 1986. Crustal scale balanced cross-sections of the Pyrenees: discussion, Tectonophysics, 129, 303-318.

Sibuet, J.-C., Srivastava, S.P. \& Spakman, W., 2004. Pyrenean orogeny and plate kinematics, J. geophys. Res., 109, B08104, doi:10.1029/2003JB002514.

Souriau, A. \& Granet, M., 1995. A tomographic study of the lithosphere beneath the Pyrenees from local and teleseismic data, J. geophys. Res., 100, 18117-18134.

Souriau, A., Chevrot, S. \& Olivera, C., 2008. A new tomographic image of the Pyrenean lithosphere from teleseismic data, Tectonophysics, 460, 206-214.

Souriau, A., Rigo, A., Sylvander, M., Benahmed, S. \& Grimaud, F., 2014. Seismicity in central-western Pyrenees (France): A consequence of the subsidence of dense exhumed bodies, Tectonophysics, 621, 123-131.

Steck, L.K. \& Prothero, W.A., 1991. A 3-D raytracer for teleseismic bodywave arrival times, Bull. seism. Soc. Am., 81, 1332-1339.

Teixell, A., 1998. Crustal structure and orogenic material budget in the west central Pyrenees, Tectonics, 17, 395-406.

Thurber, C.H., 1983. Earthquake locations and three-dimensional crustal structure in the Coyote Lake Area, central California, J. geophys. Res., 88, 8226-8236.

Tiberi, C. et al., 2008. Asthenospheric imprints on the lithosphere in Central Mongolia and Southern Siberia from a joint inversion of gravity and seismology (MOBAL experiment), Geophys. J. Int., 175, 1283-1297.

Tiberi, C., Diament, M., Déverchère, J., Petit-Mariani, C., Mikhailov, V., Tikhotsky, S. \& Achauer, U., 2003. Deep structure of the Baikal rift zone revealed by joint inversion of gravity and seismology, J. geophys. Res., 108, $1-15$.
Torné, M., De Cabissole, B., Bayer, R., Casas, A., Daignières, M. \& Rivero, A., 1989. Gravity constraints on the deep structure of the Pyrenean belt along the ECORS profile, Tectonophysics, 165, 105-116.

Vacher, P. \& Souriau, A., 2001. A three-dimensional model of the Pyrenean deep structure based on gravity modelling, seismic images and petrological constraints, Geophys. J. Int., 145, 460-470.

Vanderhaeghe, O. \& Grabkowiak, A., 2014. Tectonic accretion and recycling of the continental lithosphere during the Alpine orogeny along the Pyrenees, Bull. Soc. Geol. France, 185, 257-277.

Villaseñor, A., Yang, Y., Ritzwoller, M.H. \& Gallart, J., 2007. Ambient noise surface wave tomography of the Iberian Peninsula: implications for shallow seismic structure, Geophys. Res. Lett., 34, L11304, doi:10.1029/2007GL030164.

Vissers, R.L.M. \& Meijer, P.T., 2012a. Iberian plate kinematics and Alpine collision in the Pyrenees, Earth-Sci. Rev., 114, 61-83.

Vissers, R.L.M. \& Meijer, P.T., 2012b. Mesozoic rotation of Iberia: Subduction in the Pyrenees? Earth-Sci. Rev., 110, 93-110.

Wang, Y. et al., 2016. The deep roots of the western Pyrenees revealed by full waveform inversion of teleseismic $P$ waves, Geology, 44, 475-478.

Zeyen, H. \& Achauer, U., 1997. Joint inversion of teleseismic delay times and gravity anomaly data for regional structures, in Upper Mantle Heterogeneities from Active and Passive Seismology, Vol. 17, p. 155-168, ed. Fuchs K., Springer.

Zeyen, H. \& Fernàndez, M., 1994. Integrated lithospheric modeling combining thermal, gravity, and local isostasy analysis: application to the NE Spanish geotransect, J. geophys. Res., 99, 18089-18102

Zhu, H., Bozdag, E., Peter, D. \& Tromp, J., 2012. Structure of the European upper mantle revealed by adjoint tomography, Nat. Geosci., 5, 493-498.

Ziegler, P.A. \& Dèzes, P., 2006. Crustal evolution of Western and Central Europe, Geol. Soc., London, Mem., 32, 43-56. 